العمليه الاتتخابيه وي الدول العربيه الدواقع والمعوفات

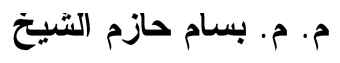

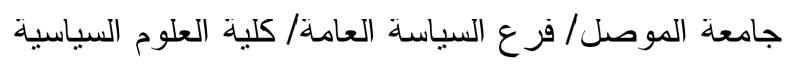

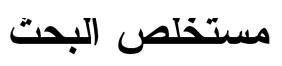

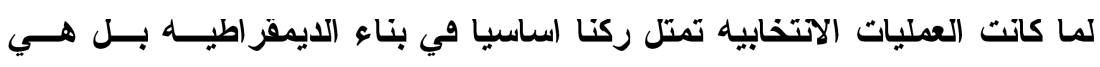

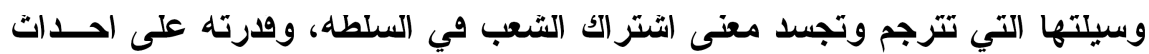

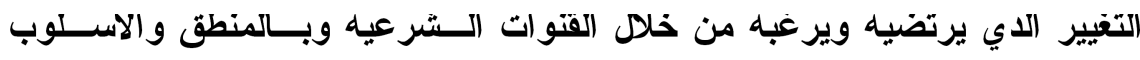
القانوني الصحيح.

ولعل دلك المفهوم يعد تجسيدا لما يحدت في معظم دول العالم ولايما وحديتا ومن

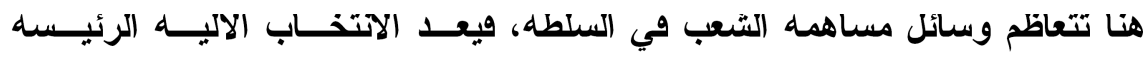

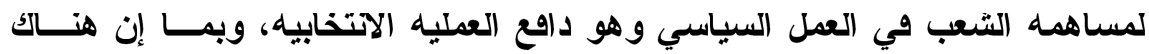

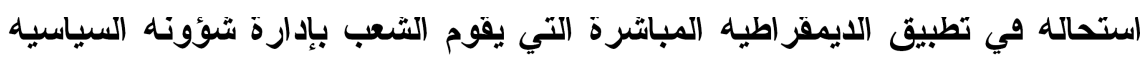

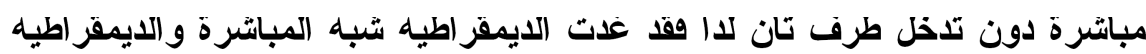

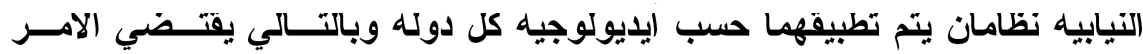

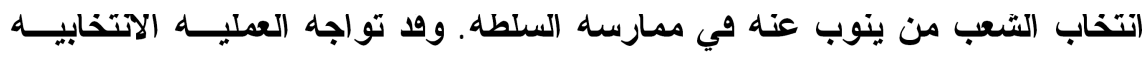

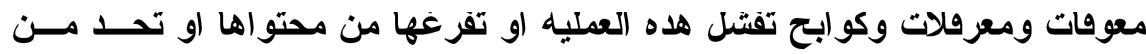

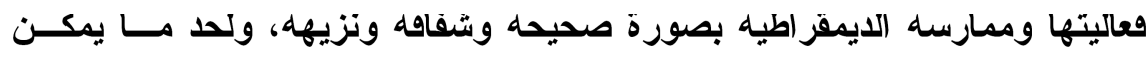

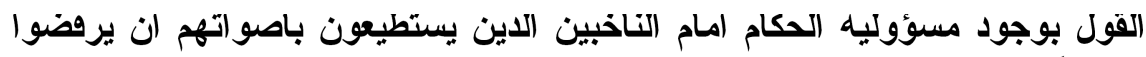

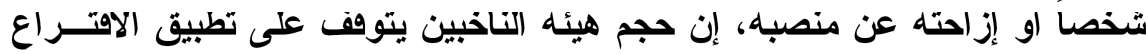

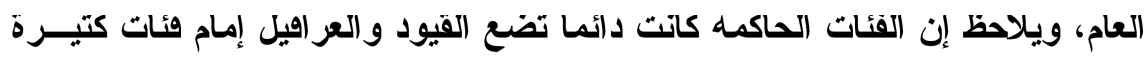
من المواطنين لتحجب عنهم الاتخابات وبالتالي تقليص حجم هيئه الناخبين إلى الحدات الادنى. 
ليس هناك شكا بان العملية الديمقر اطية في اي بلد من البلاد قد شهدت

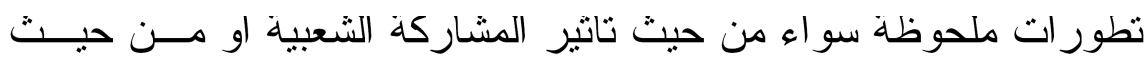

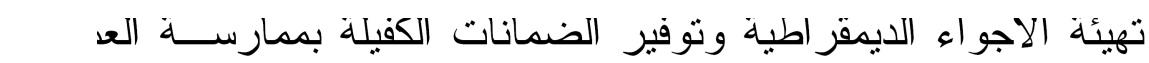

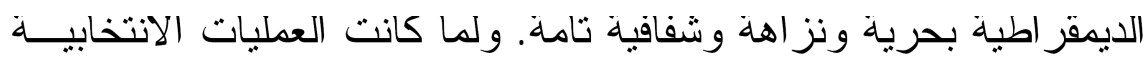

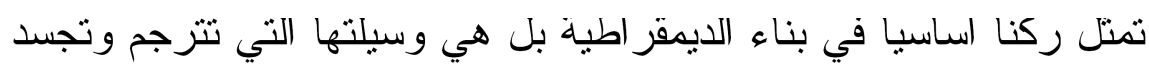

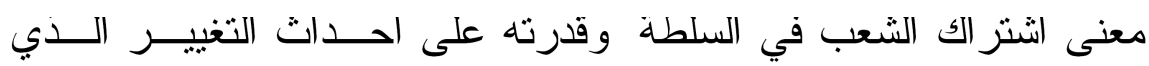
يرتضيه ويرغبه من خلال القنوات الثرعية وبالمنطق و الاسلوب القانوني الصحيح. ويقضضي مبدا مشاركة الشعب في السلطة وسائل و اليات لتفعيل هــــه

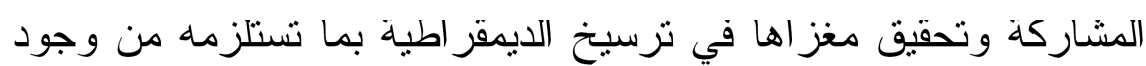
اتجاهات للمعارضة، فإن كانت الحكومة تثمتع بسلطات و اسعة في تحقيق اغر اض الدولة المختلفة إلا انه في بعض الاحوال النهات قديء استخدام هذه

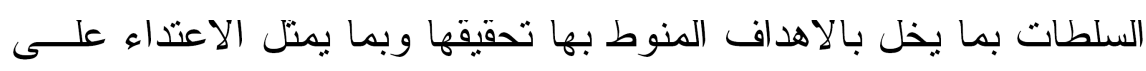
الحقوق و الحريات. ولعل ذلك المفهوم يعد تجسيدا لما يحدث في معظم دول العالم قـديما

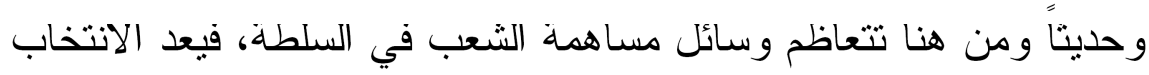
الالية الرئيسة لمساهمة الشعب في العمل السياسي، وبما إن هناك استحالة

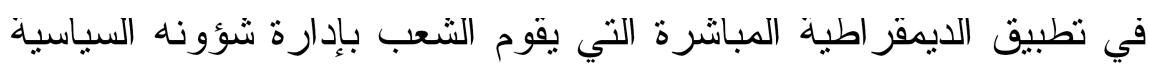

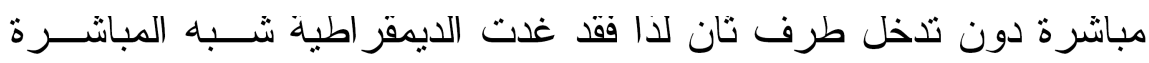

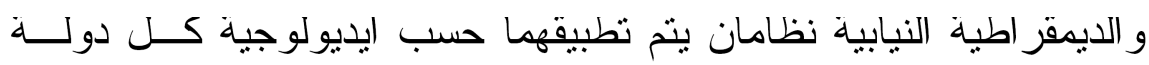
وبالتالي بقتضي الامر انتخاب الشعب من ينوب عنه في ممارسة السلطة. 
دواقع العمليه الاتتخابيه: بدعى الجسم الانتخابي إلى التعبيز عن إرادتـــه

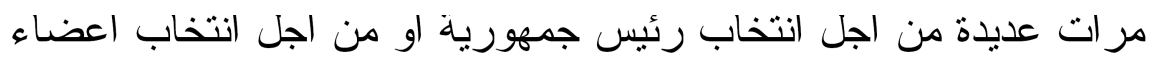

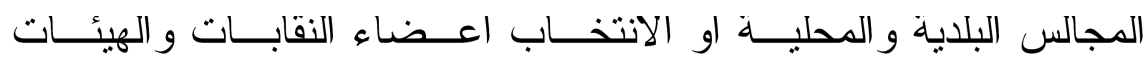

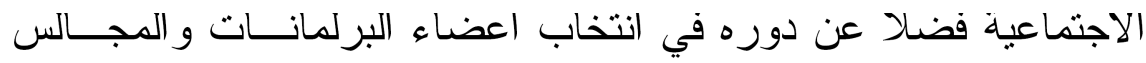
النيابية، او للمو اققة على مشروع دستور ، او للمو اققة على تبـــديل نظـــــام الحكم، ففي كل هذه الحالات يبقى حق التصويت سلطة رابعة، مضافة إلى لى لئل سلطات الدولة التناث. وتبقى عملية الانتخاب ضرورية بالنسبة للحكــام

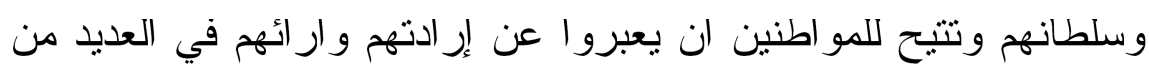
المسائل التي تمس حياتهم، فالاقتز اع هو في الدرجة الاولى تلى تنظيم سياسي

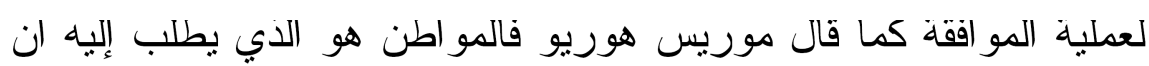

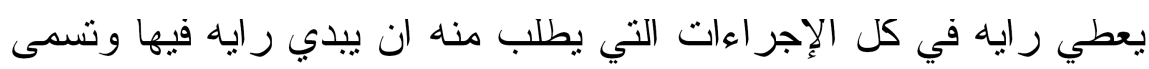
الإجر اءات الانتخابية .

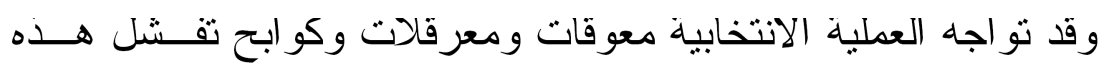

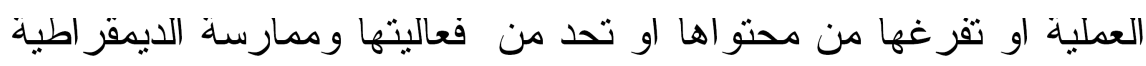
بصورة صحيحة وشفافة ونزيهة، ولحد ما يمكن القول بوجود مـسؤولية

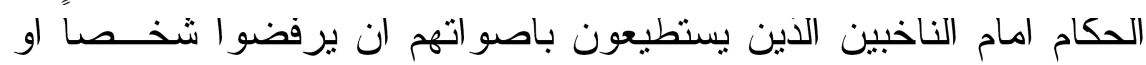

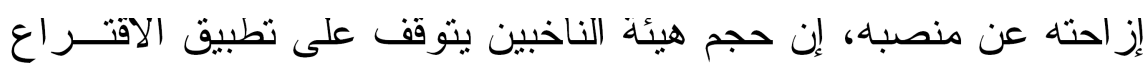

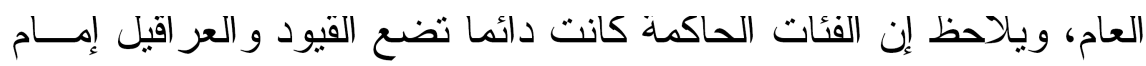
فئات كثيرة من المو اطنين لتحجب عنهم الانتخابات وبالتالي تقليص حجم ونم

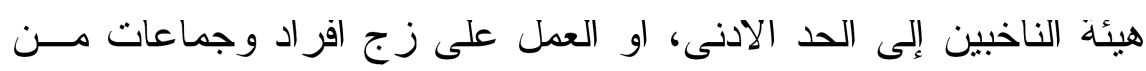

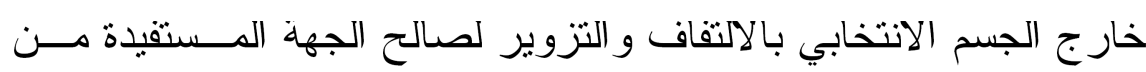
طبيعة النتائج الانتخابية. 
بناء على ما قد سلف فقد تم تقسيم البحث إلى تلاثث مباحث، المبحـــث

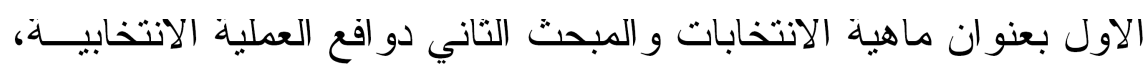
اما المبحث الثالث والاخير تحت عنو ان معوقات العملية الانتخابية.

الإشكالية التي يحاول البحث التطرق إلبها وعرضها ومحاولة إيجــاد الحلول لها دو افع العملية الانتخابية ومعوقاتها . فالديمقر اطية الانتخابية لها دو افع تقوم بالتز غيب و الدفع بالعملية الانتخابية إلى الامام وبمسنوى علمي لإني

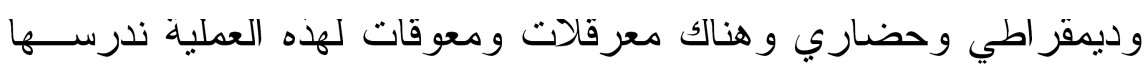

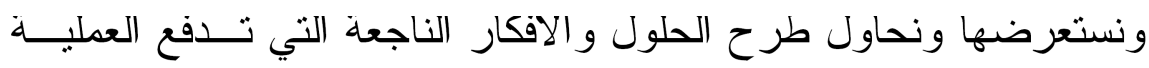
الانتخابية إلى النطبيق الامتل. ونهاول.

\section{منهجيه (البحث}

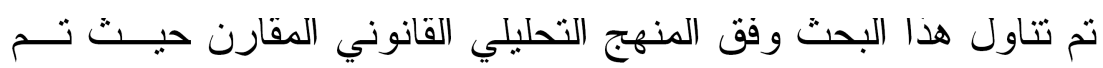
تحليل النصوص الدستورية والقانونية وايضا استخدام المنهج التـاريخي لدر اسة ما كانت علية الديمقر اطية الانتخابية وتطور ها التاريخي. 


\section{المبحث الاول \\ ماهيه الاتتخابات}

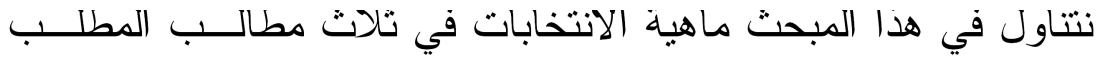

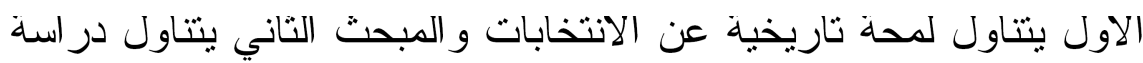

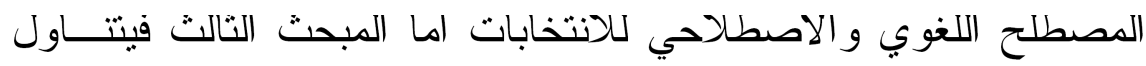
المفهوم القانوني و السياسي للانتخابات.

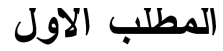 \\ لمحه تاريخيه}

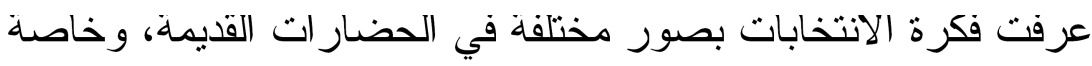

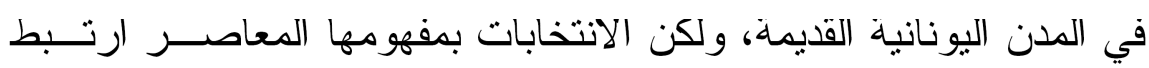

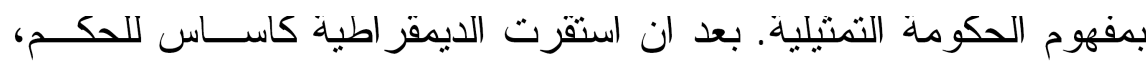

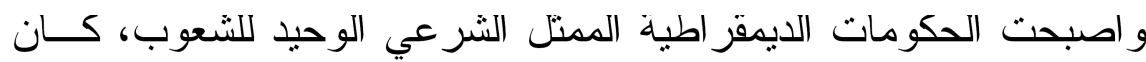

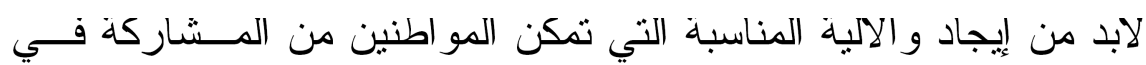

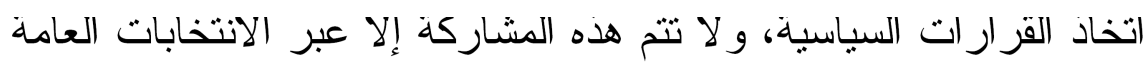
الني تمكن الشعب من اختيار ممتلبه. في اواخر القرن الحادي عشر اشتندت المنازعات بين البابوية و الملوك

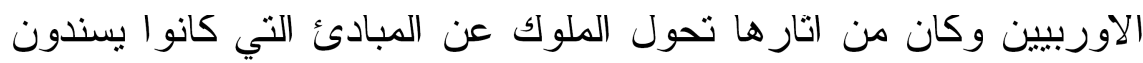

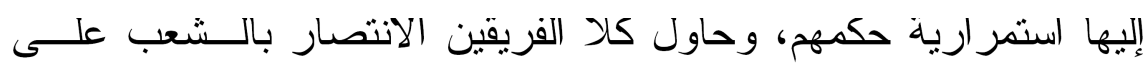

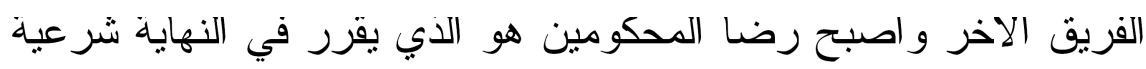

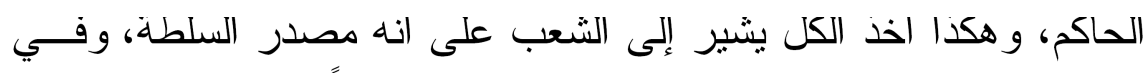

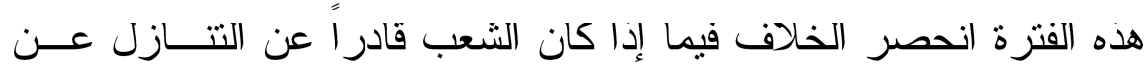
سلطته بالتقويض (1) وكان هذا الصر اع بمثنابة الخطوة الاولى فــي ســبيل نــشـاة النظـــام

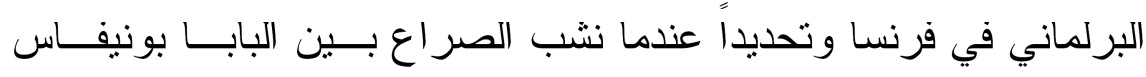


التامن وملك فرنسا فيليب وبعد الثُد و الجذب لسنوات بين كلا الطـــرفين

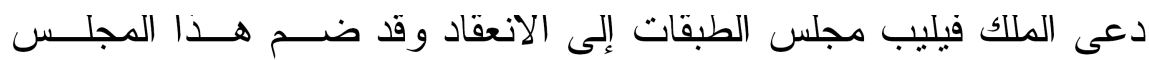

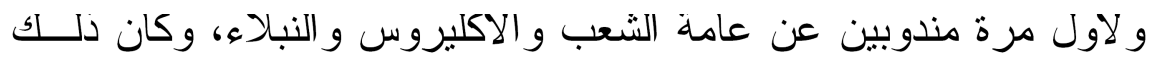

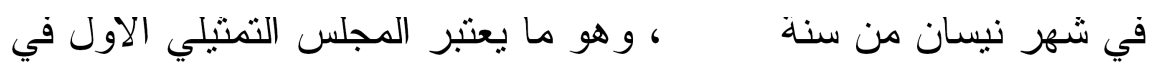

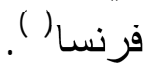
اما بالنسبة للبرلمان الانكليزي فتعود نشاته إلى المجلس الكبير الــذي لــي

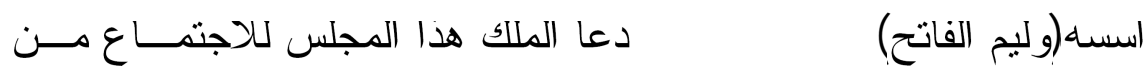

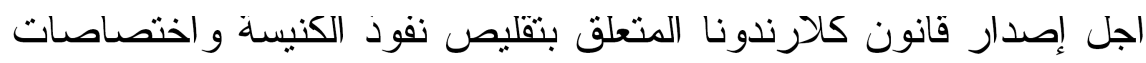
محاكمها، وحصل بين الطرفين نزاع طويل الامد حتى انتهى بتوقيع اثنهر وثيقة سياسية بالتاريخ الانكليزي و المسماة العهد الاعظم (الماكانا كارنا)،

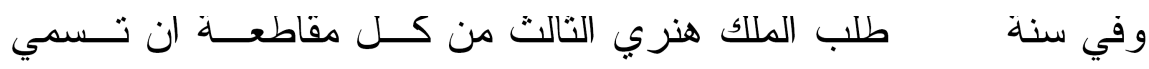

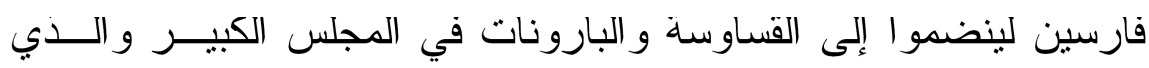

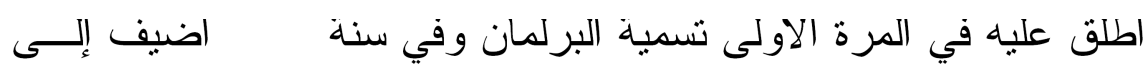

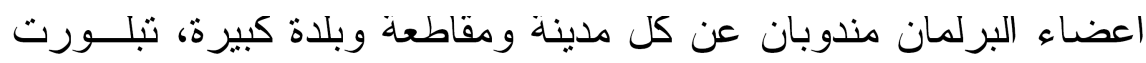

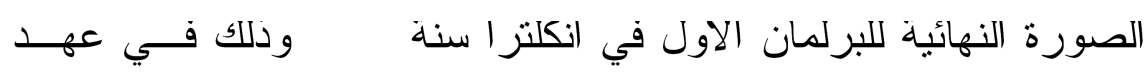

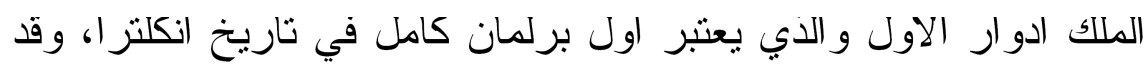
جاء في مرسوم الدعوة (إن ما يمس الجميع ينبني ان يكون موضع مو افقة

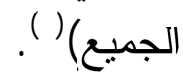
ولما ظهر الحق السياسي الليبر الي، لم يكن على صورة و احدة، بل

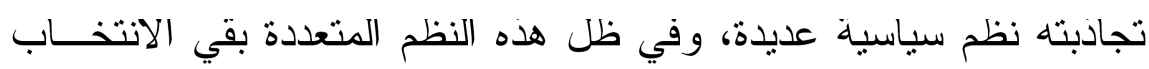

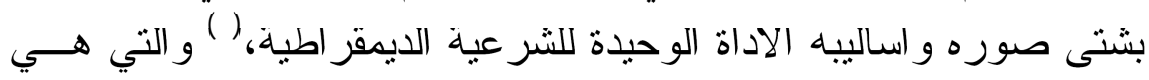

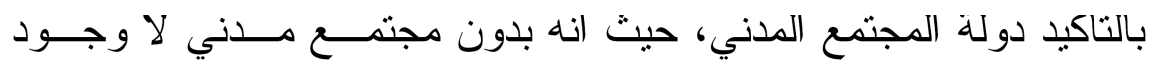

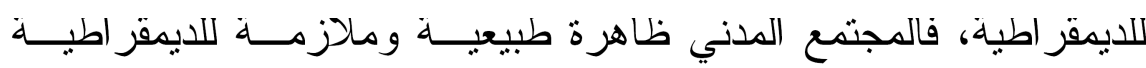
التمتيلية، لان غياب هذا المجتمع لا يؤدي إلى ترسيخ الحرية و إنما يغذي في فئي

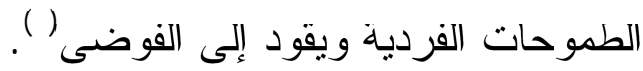


وتتميز الشر عية الديمقر اطية عن سابقتها، بان الحكام بمثلون الــشعب في سعيهم لتحقيق المنفعة العامة بثقويض منه، بينما كانو ا يمثلونه في ما لئه

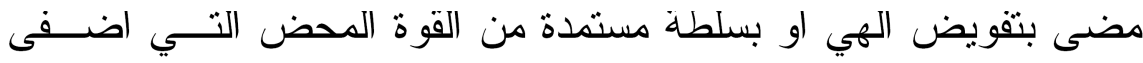
عليها التقليد صفة الشرعية، ويمكن القول بان النتثنل السياسي في الحكم

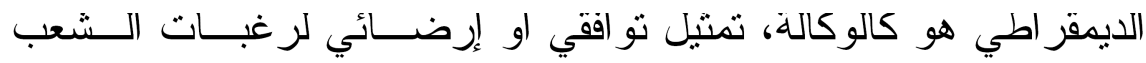

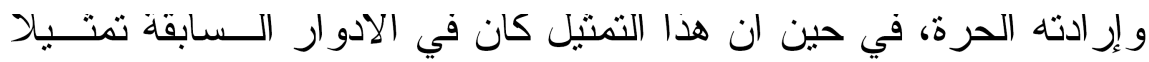

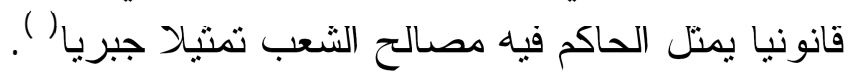

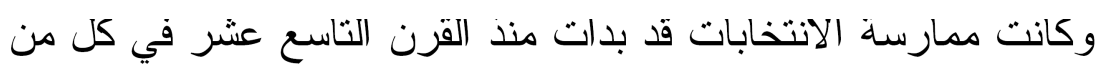

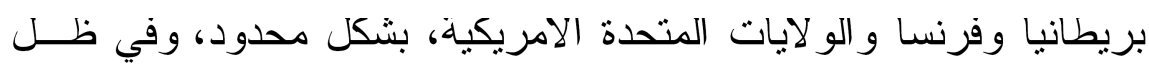

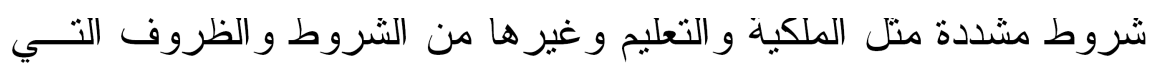

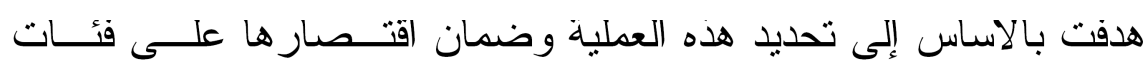

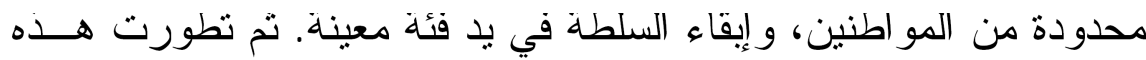

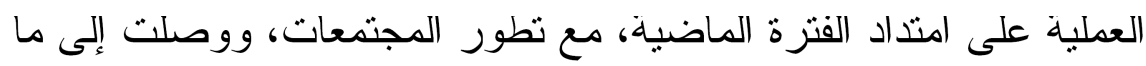
وصلت إلبه في العصر الحالي، حيث اصبح للانتخابات قو اعد وقـــو انين

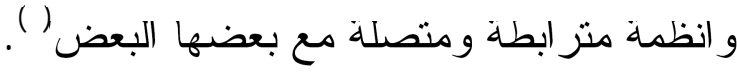
ويمكن تقسيم الانتخابات إلى انو اع عدة منها:

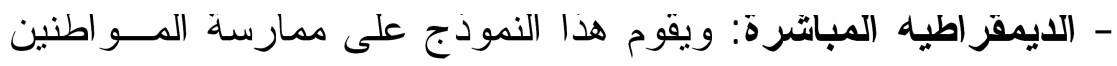

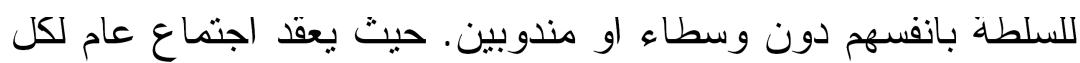

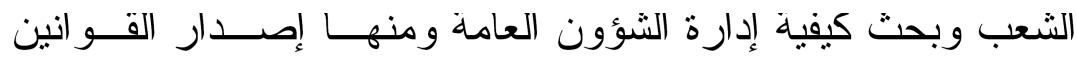

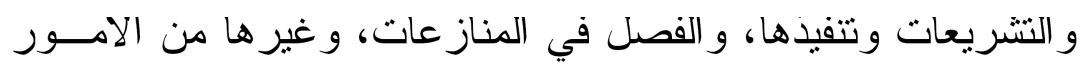

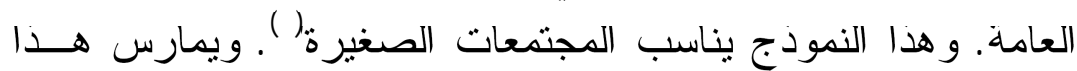

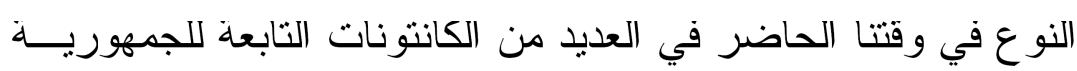
السويسرية

- الديمقر اطيه شبه المباشرة: ويقوم هذا النمودج مــن الــديمقر اطيات على اساس المزج بين كل من صور الديمقر اطية النيابية التي تقطـــع 
كل صلة لها بالشعب بعد انتخاب اعضاء البرلمان وبين الديمقر اطبة، ويباشر الشعب سلطاته عن طريق عدة مظاهر يطلق عليها مظـــاهر

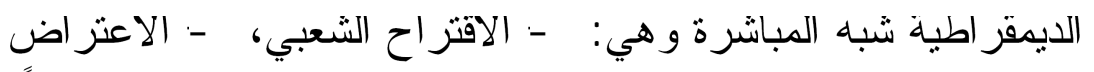

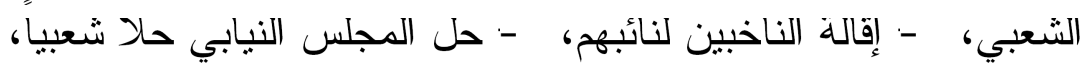
- عزل رئيس الجمهورية، - الاستفتاء الشعبي (·).

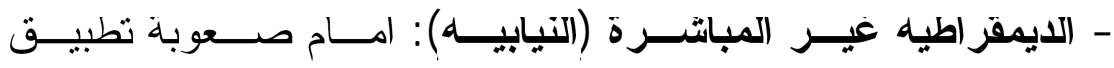

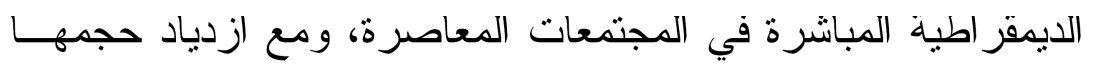

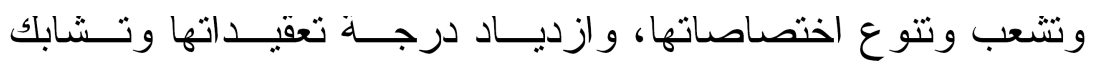
المصالح فيها فانه لا بد من تطبيق هذا النموذج الذي يتمنل جو هره في

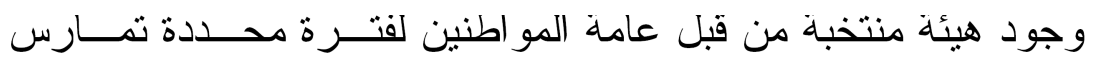

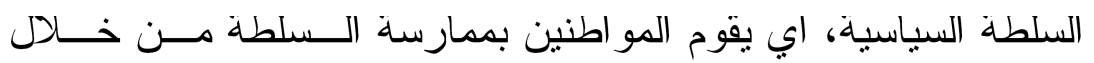
مندوبين او وكلاء يمتلونهم وفي هذه الديمقر اطية ينقسم الانتخاب فيها إلى نو عين:

الاتتخاب المقيد: حيث بتم وضع قيود وشروط معينه للمشاركة فيها، و هذا النوع لا يناسب المجتمع الديمقر اطي.

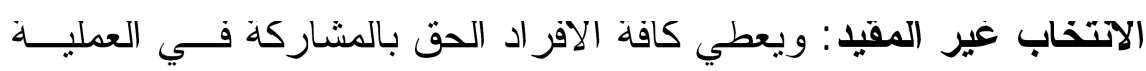

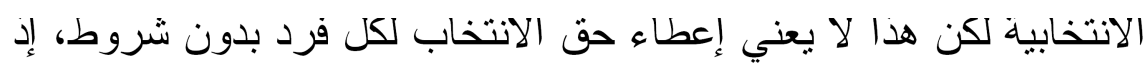

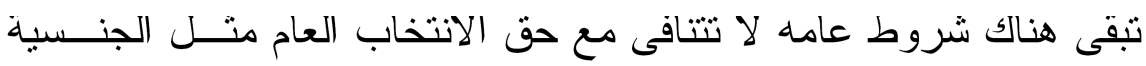
و السن و الاهلية العقلية. (II) المطلب التاني

الاتتخاب لغه و اصطلاحا

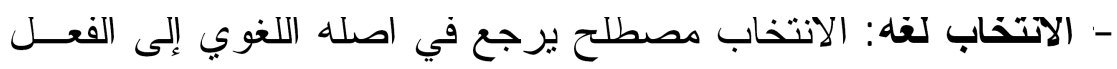

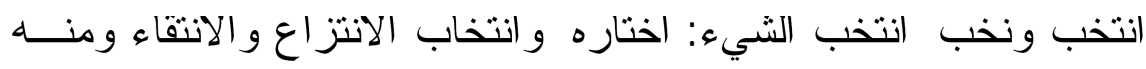


النخبة: وهم جماعة تختار من الرجال او هم المنتخبون من النــاس، اي المنتقون، و النخبة بالضد: المختار و انتخبه اختاره(باء).

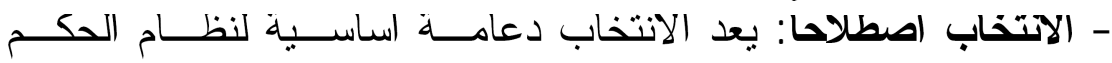

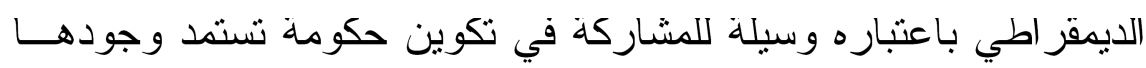

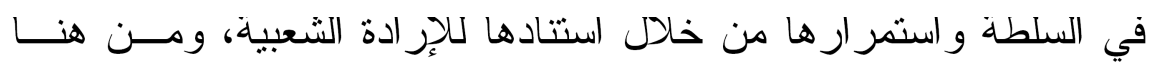
يظهر الانتخاب كوسيلة للاتصال بين الحكام و المحكومين، و امام استحالة

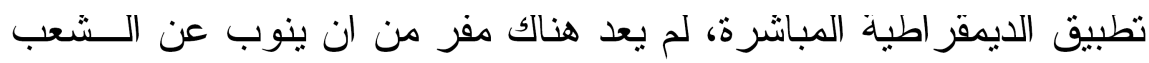

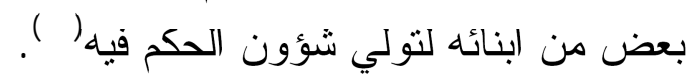

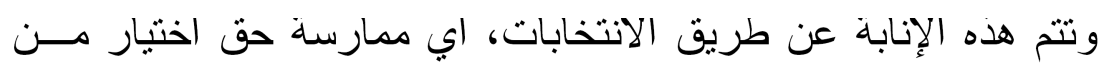

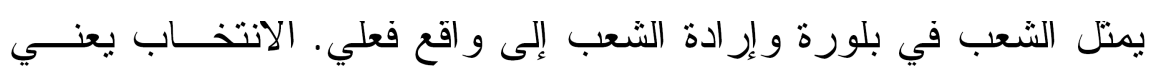

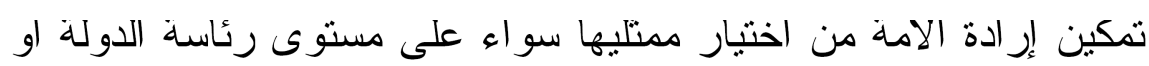

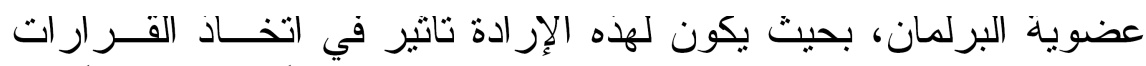

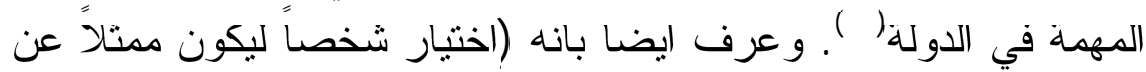

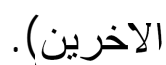

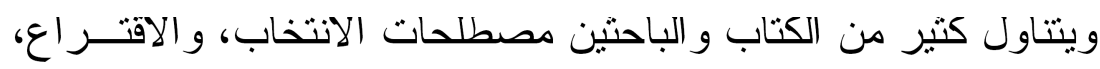
و التصويت كمر ادفات، على الرغم من الاختلاف في المدلول الاصطلاحي

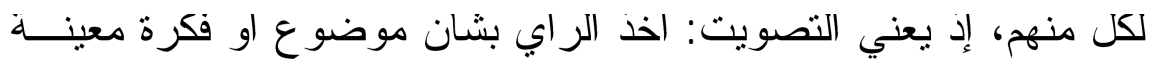

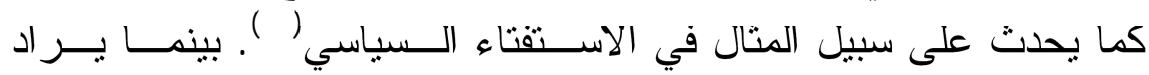

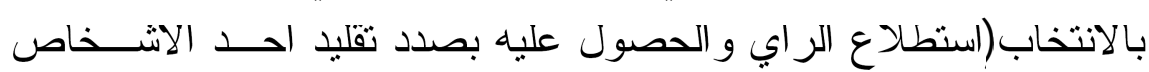

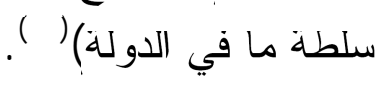

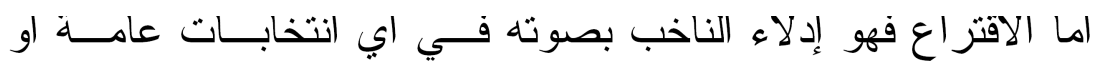
استفتاء عام، اي إن الاقتر اع اوسع مدلو لا من التصويت و الانتخاب (IV). 


\section{المطلب التالث \\ المفهوم القانوني و السياسي للاتتخاب}

الانتخاب هو تمكين المواطنين الذين تتوفر فيهم الشروط القانونية فــي

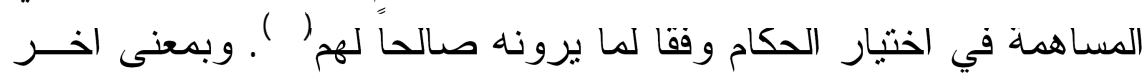

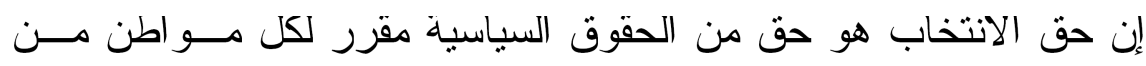
مو اطني الدولة حيث يكون له ممارسته بما من شانه التعبير بحرية كاملة هنية

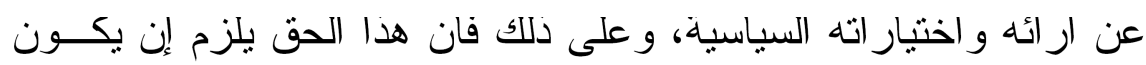

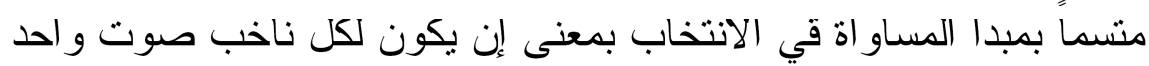

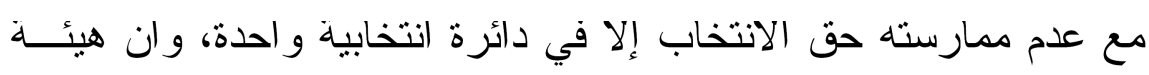

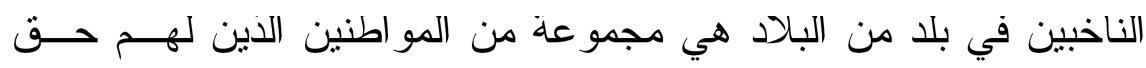

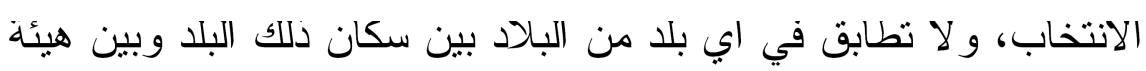
الناخبين (19)

وقد اختلفت الاراء في شان تحديد الطبيعة القانونية للانتخاب وقد ذهبوا

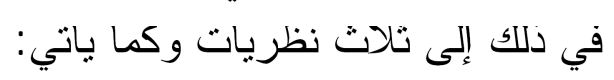

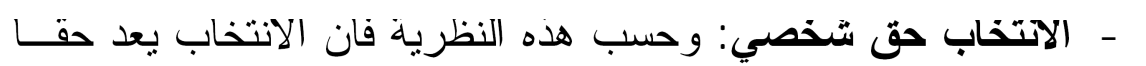

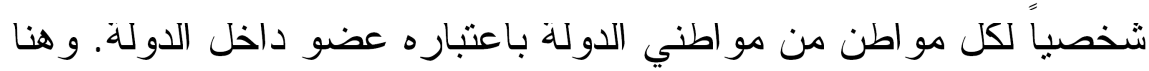

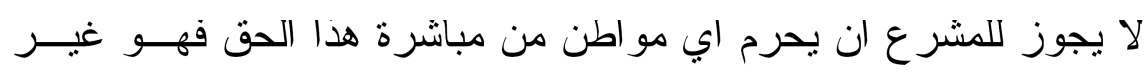

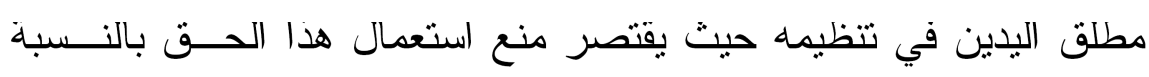

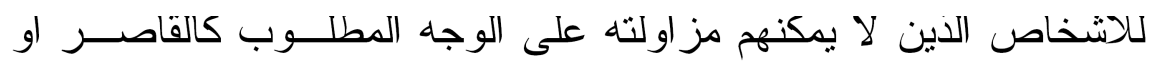

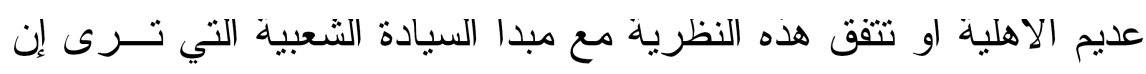

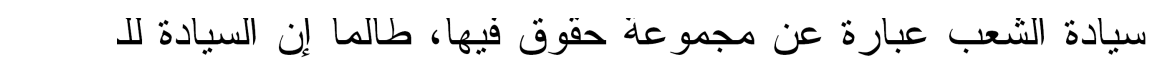


فانه على التبعية يكون من حق الجميع ممارسة هذه السيادة مــن خــلال

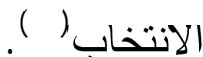

r - الاتخاب وظيفه: يعد الانتخاب وفق مبدا سيادة الامة وظيفة لاحقا من الحقوق السياسية للافر اد فوفقا لهذا المبدا لا يكون انتخاب الاشخاص القائمين على ممارسة السلطة حقا و إنما وظيفة يجب على الاقر اد القيام بها، و عليه إن مبدا سيادة الامة لا بتعارض مع نظام الاقتز اع المقيد حيث تستطيع الامة ان تقبد حق الاقتز اع بشرط النصاب المالي او شرط التعليم او شرط الانتماء إلى طبقة اجتماعية معينة حتى تقبل في النهاية توفر الكفاءة في من بتم اختيار هم

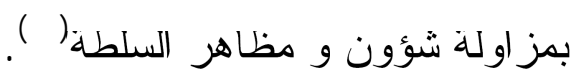

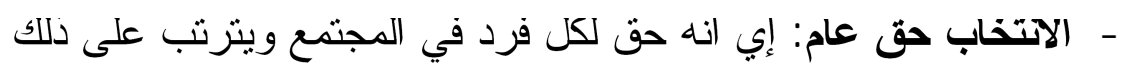

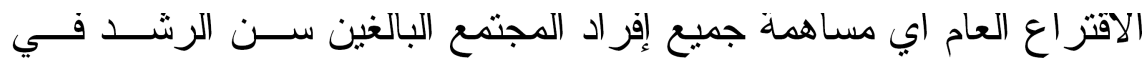

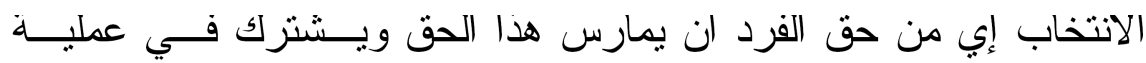

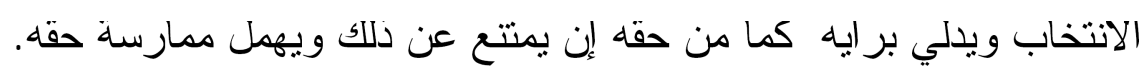

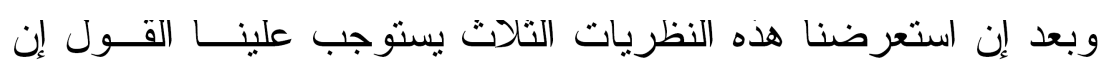

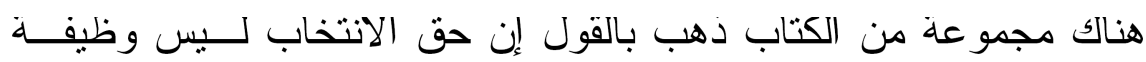
و لاحق عام او شخصي بل هو سلطة قانونية مصدر ها الاساسي الدستور الذي ينظمها من اجل اشتر اك المو اطنين في اختيار الحكام (rr).

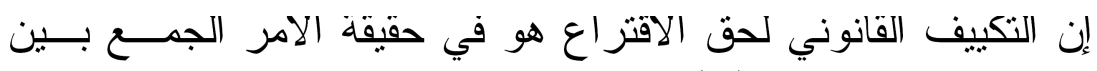
الفكرنين فهو حق ووظيفة (بّ).

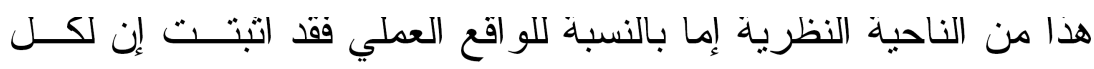

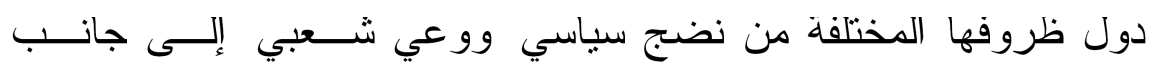

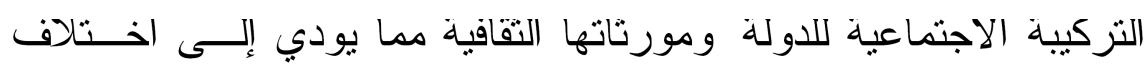


التنظيم الفعلي للانتخابات من دولة و اخرى بل قد يختلف في ذات الدولـــة

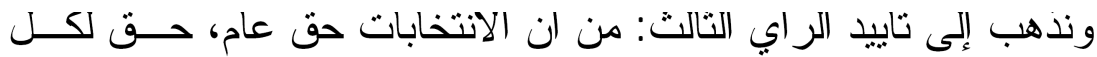

فرد بالغ عاقل أن يساهم في المشاركة أو عدم المشاركة في الاقتر اع العام. العاب.

المبحث التاني

\section{دواقع العمليه الاتخابيه}

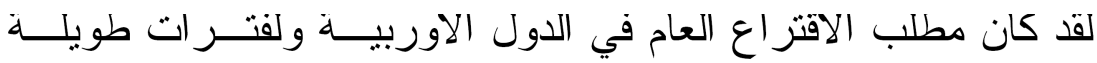
مطلباً اساسيا ناضلت من اجل الحصول علية الجماهير التي كانت قو انين التين

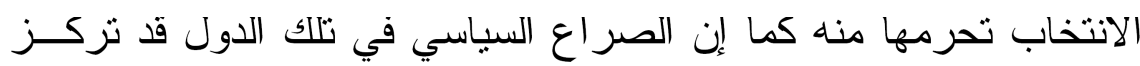

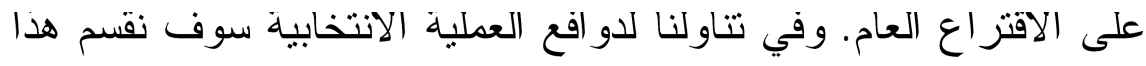

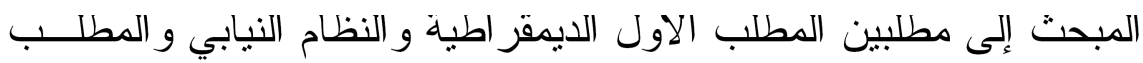
الثاني نتناول فيه تاثير الانتخاب في الاحز اب السياسيخ وجماعة الضغط.

$$
\text { المطلب الاول }
$$

\section{الايمقر اطيه و النظام النيابي}

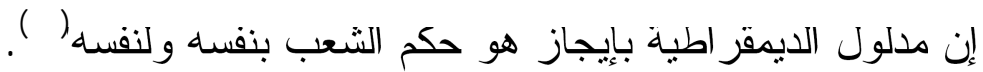

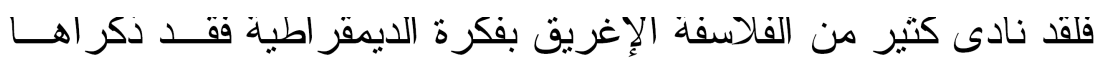

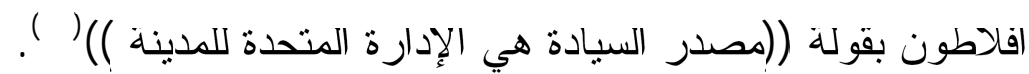

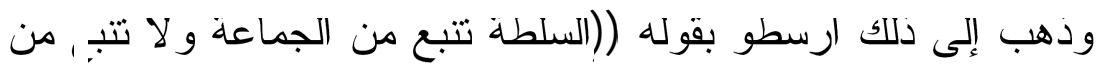
شخص الحاكم بذاته)(TV) (TV)

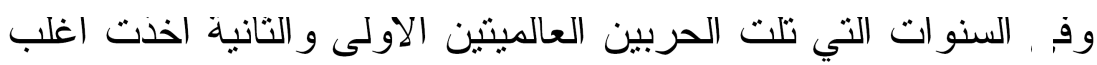

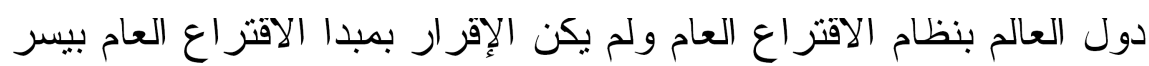

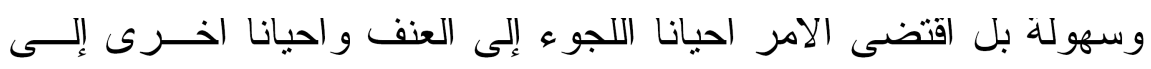

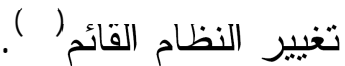


وقد نص دستور فرنسا على السيادة الشعبية وســلطة الــشعب حبـــث

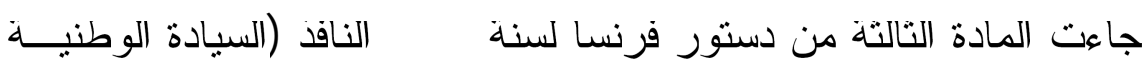

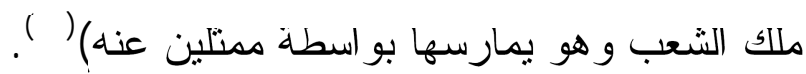
ونصت المادة الثالثة من دستور جمهورية مصر بور العربية لسنة (السيادة للشعب وحده و هو مصدر السلطات ويمارس الشعب هذه السيادة

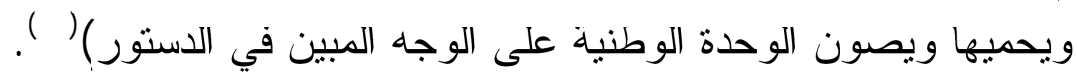

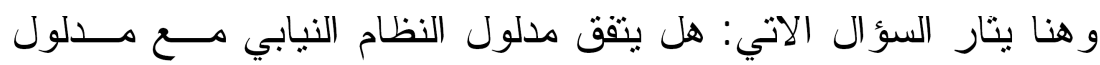
الديمقر اطبة"؟ وللإجابة على هذا التساؤل نقول: لقد تتازعت نظريتين لشرح النوافق بين النظام النيابي و الديمقر اطية النظريه الاولى: نظرية النيابة (مبدا سيادة الامهة) من مقتضى هذه النظرية إن نو اب الشُعب يمارسون مظاهر السيادة نيابة عن افر اد الشعب باعتبار إنهم بمثنابة وكلاء عن افراد الشُعب ونتيجة

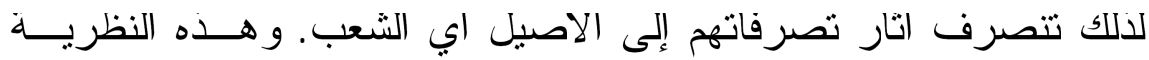

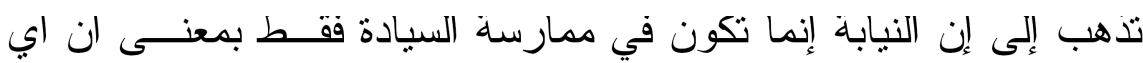
عمل صادر عن نواب الامة يعد وكانه صادر عن الامة نفسها (ابان.

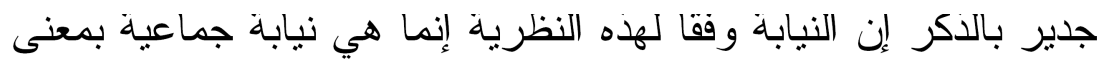

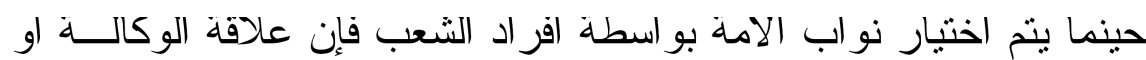

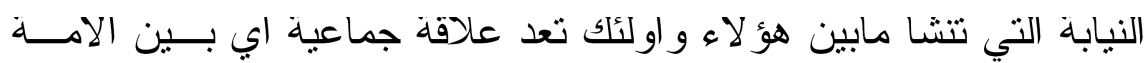

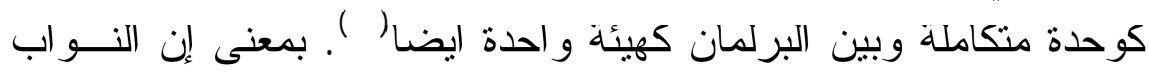

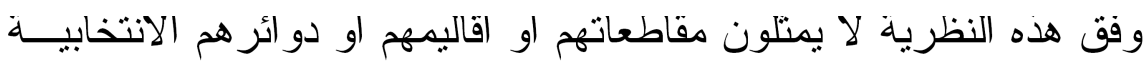
فقط بل بمثلون الامة بكاملها. النظريـه التانيه: نظرية العضو (مبدا سيادة الشعب) إن السيادة وفق لهــــهـ

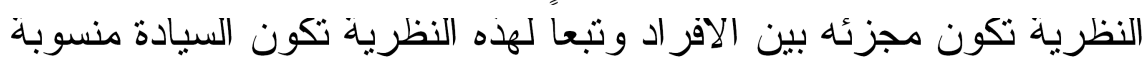
إلى افر اد الشعب وتكون السيادة مجزئة ومقسمة بين هؤ لاء الافر اد و الذين 
يكون لكل و احد منهم نصيب فيها. و عليه يكون لكل منهم حق ذاتي فـي

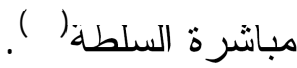

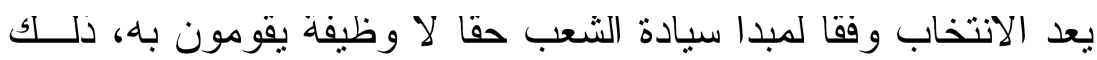
باعتبار إن كل فرد من افر اد الشعب يمتلك جزء من السيادة فيكون له حق ون اله

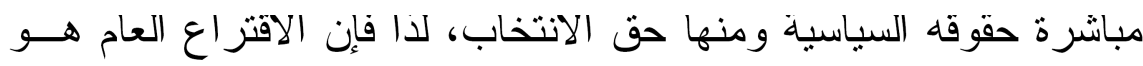

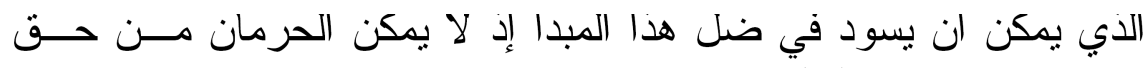
الانتخاب لاي سبب (عَ). ويعتبر الناخب في البرلمان ممتلا عن ناخبيه فقط

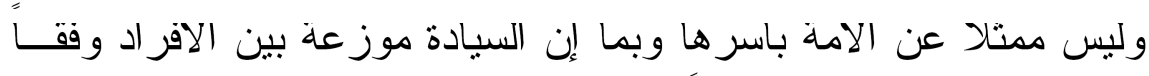

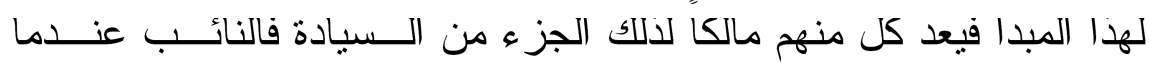

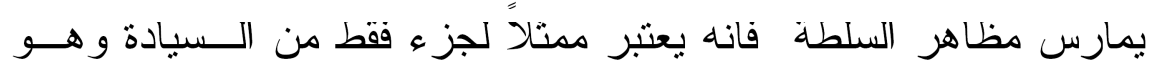
الجزء الذي بملكه ناخبوه (ro).

من مضمون السيادة الشعبية المتمنل في النظرينتين (سيادة الامة وسيادة

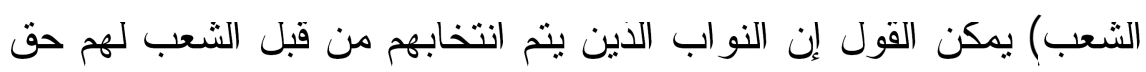

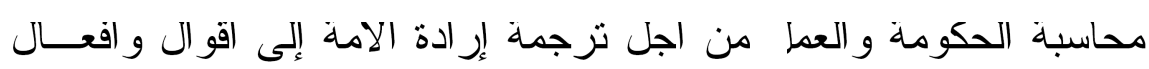

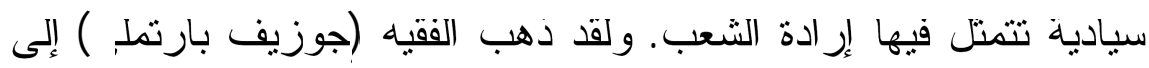

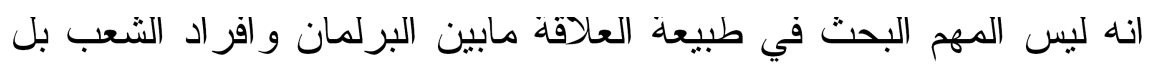
الاهم هو ضمان اشتر اك الشعب في امور الحكم سو اء تمت هذه المشاركة بالطريق المباشر اي اللجوء إلى افر اد الشعب مباشرة، او بطريقة غيــر مباشر وذلك بو اسطة النو اب البرلمانيين (باء). وقبل ان نختم هذا المطلب نعرج على سمات الديمقر اطبة النيابية وهي على النحو التالي:

1 - وجود برلمان منتخب: يعد الركن الاول مــن اركـــان الديمقر اطيـــة

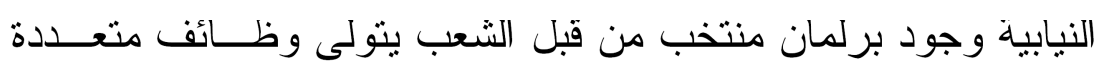

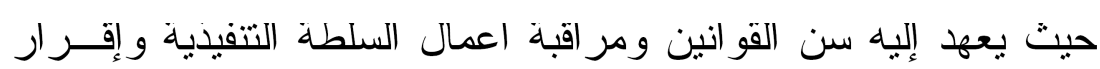

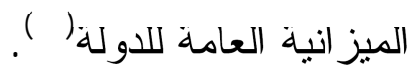


r - تاقيت مدة البرلمان: وحسب هذا الركن فإن البرلمان المنتخب يلــزم

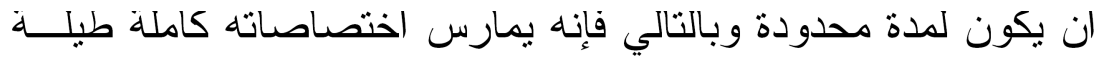
هذه المدة التي تختلف من نظام دستوري إلى اخر وجرى العمل على ونى ان نكون مدة البرلمان ما بين ثناث سنوات وخمس سنوات ثم بجددوا

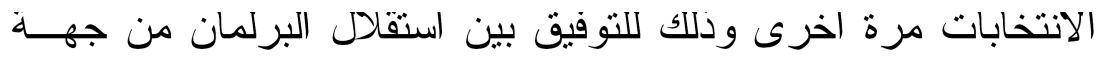
و الاحتقاظ بسلطة الشعب من جهة اخرى، ولكي يكون اعضاء البرلمان

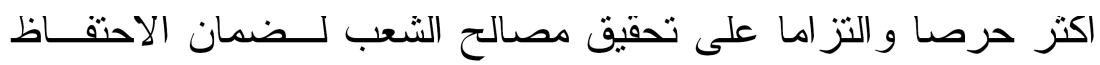

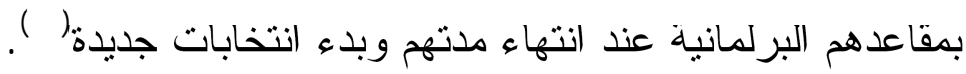

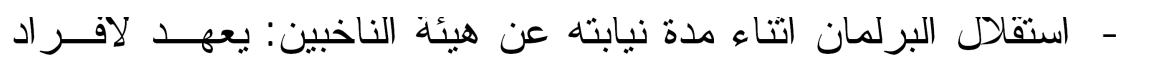
الشعب اختيار نو اب البرلمان من خلال العملية الانتخابية حيث يصبح هله

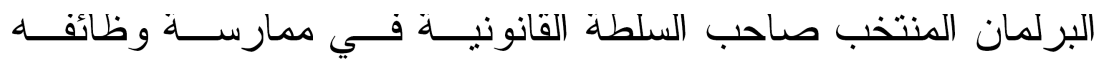

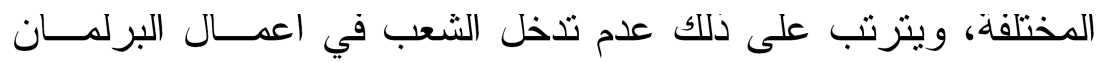
سواء باقتر اح القوانين او التصويت عليها بمعنى إن السيادة الفعلية في

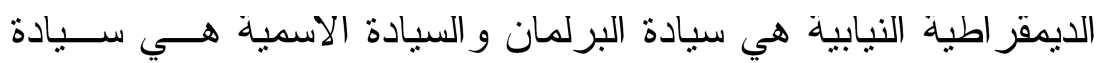

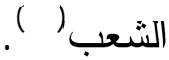

ع - عضو البرلمان ينوب عن الامة كلها: يستلزم النظام النيابي ان يمتل عضو البرلمان الأمة باسرها حيث لا يقتصر هذا التمثيل على دائرته الانتخابية فقط وبالتالي يسعى النواب إلى تحقيق المــصلحة القوميــة

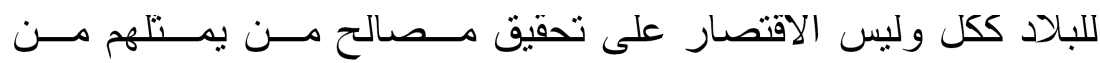


يعرف الحزب السياسي بعدة تعاريف فقد ذكر بانه (جماعة منظمة ذات

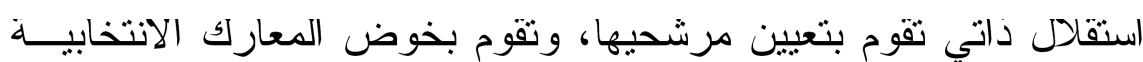

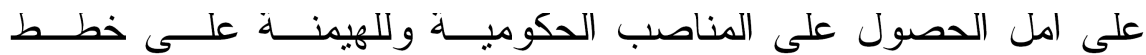

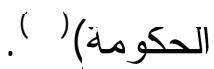

ويعرفه الاستاذ (سليمان الطماوي): ((بانها جماعة متحدة من الافــر اد

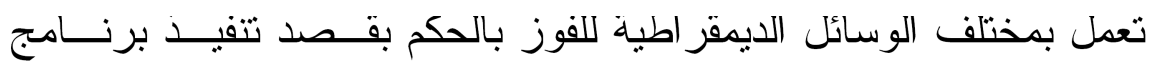

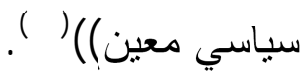
لكي يجسد مفهوم الديمقر اطية الني هي حكم الشعب بالشعب و لاجـلـل الشعب، ولكي بحقق هذا المفهوم فعلاً، يجب ان تكون سلطة الحكم الفعلي

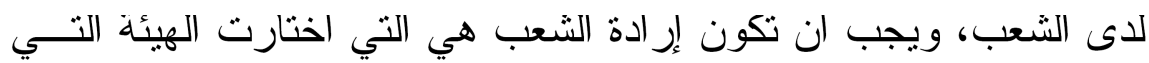

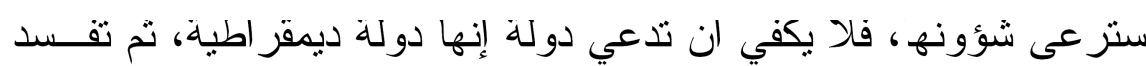

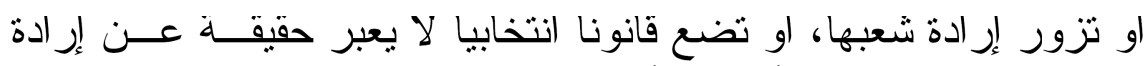

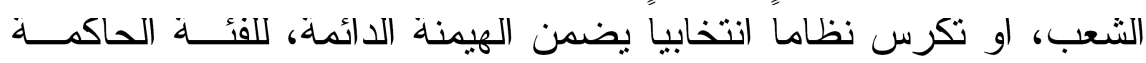

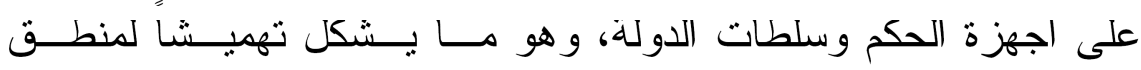

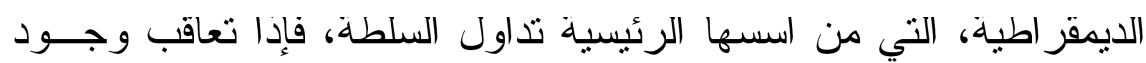

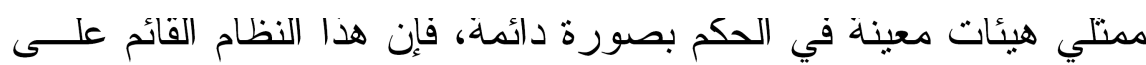
غياب منطق تداول السلطة هو بالتاكيد نظام مشكوك بديمقر اطيته.

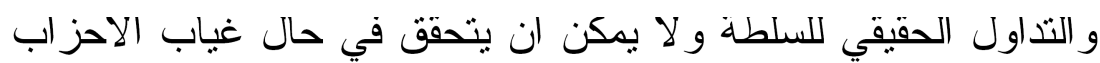
السياسية الفعالة و الوطنية التي تنتافس في ما بينها على تحقيق مــصلحة الوطن و المو اطن و هذه الاحز اب لن تقوم لها قائمة في ضل نل نظام انتخابي غبر سليم. وفي هذه الحلقة الدائرية، حيث بصعب فصل المتر ابطات القائمة بــين الاسس المكونة لمجتمع يرغب في اعتتاق الديمقر اطية كمذهب للحكم، كان

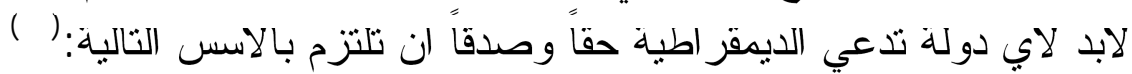
- نظام انتخابي فعلي وحقيقي. 
- الفصل بين السلطات وتداولها.

$$
\text { - و وجود أحز اب متعددة وفعالة. }
$$

- ت - تداول السلطة.

- حماية الحقوق و الحريات وفي مقدمنها الحقوق السياسية.

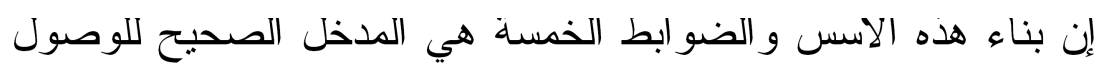

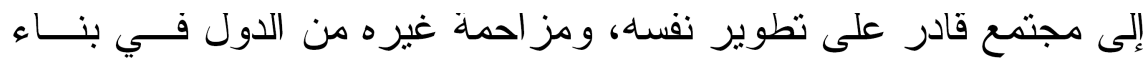
الحضارة الإنسانية واول خطوة في هذا البناء تكون باعتماد نظام انتخابي

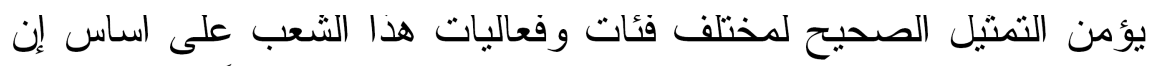

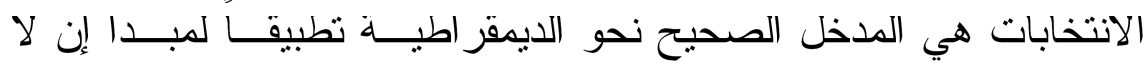

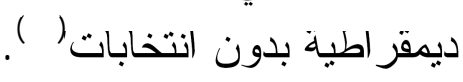
لقد تكونت اللجان الانتخابية تحت تاثير عامل هام رئيسي وهو تقرير

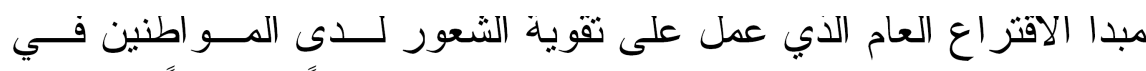

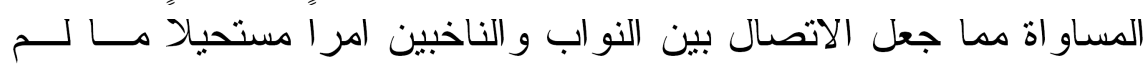

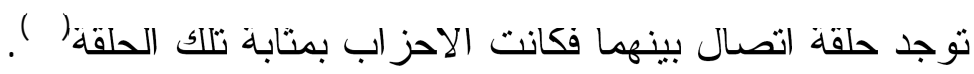
وقد ترتب على وجود المجموعات البرلمانية و اللجان الانتخابية قيــام

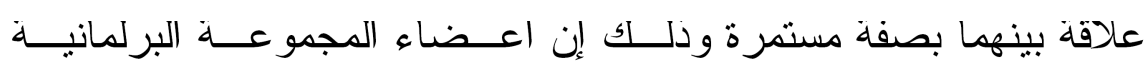
مرتبطون بها وبمجمو عتهم الانتخابية ومن هنا تم الارنباط بين التتظيمين

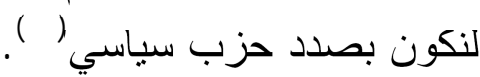
إن الاحز اب السياسية هي ضرورة ديمقر اطية وان معظم دول العــالم

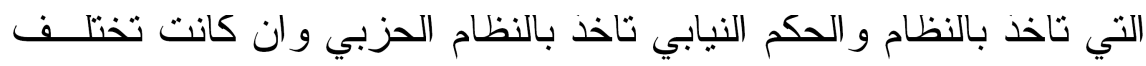
في الاخذ بنظام الحزب الواحد او تعدد الاحزاب او نظام الحزبين علــى بـى بـاني

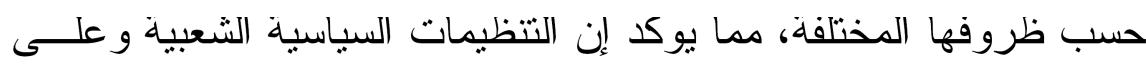

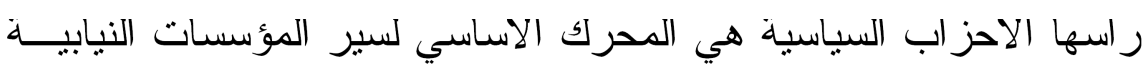

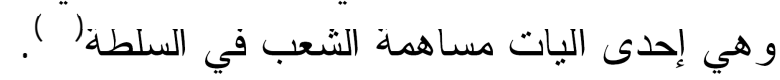


فالانتخابات هي المجال الطبيعي و الشرعي للاحز اب في وصولها إلى

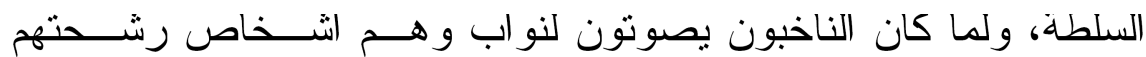

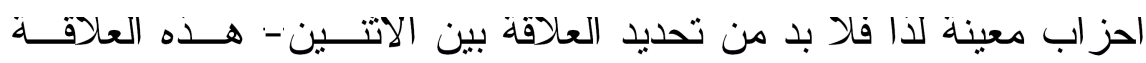

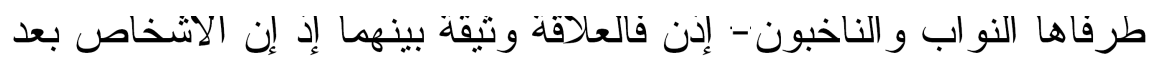

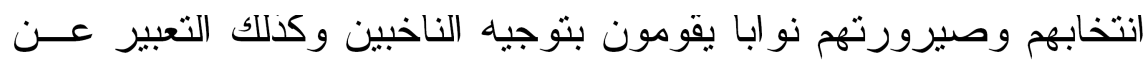

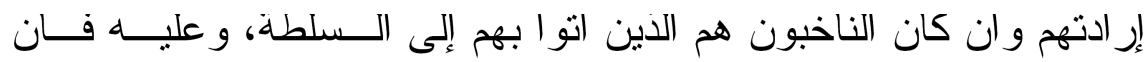
الناخب يلعب دوراً كبيراً هو الاخر في حياة الاحز اب السياسية.

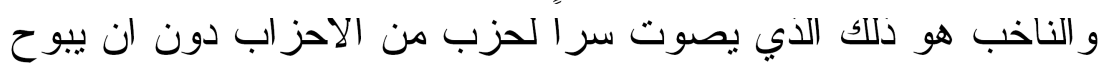

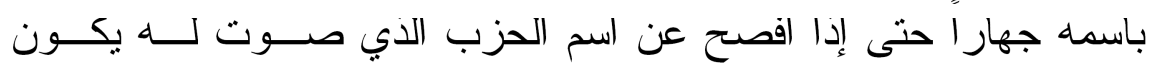
الناخب قد انتقل من مرثبة الناخبين إلى مرثبة المؤازرين.

r - جماعه (الضغط

يمكن إن نعرفهم على انهم جماعة منظمة او غير منظمة من الإفــراد

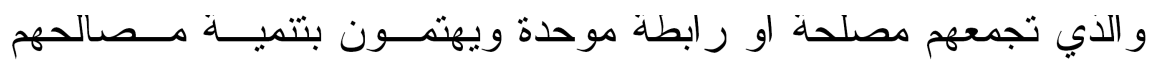
بو اسطة التاثير على الراي العام وممارسة الضغط على صانعي القرارات الحكومية للتاثير عليهم محاولة للوصول إلى السلطة، وتسمى هذه الجماعة ولئ

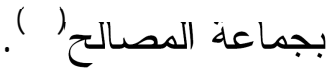

وتعمل جماعة الضغط إلى رفع مطالبها إلى ذوي الشّان باشكال مختلفة

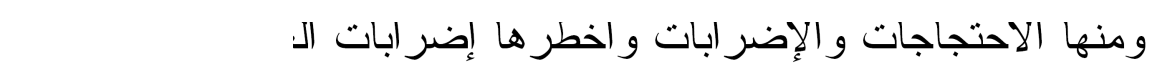

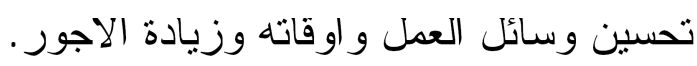
وهذه الجماعات توثز في الإفر اد من الناخبين النفسية و الاجنماعية فلقد اثبت البحوث و التجارب العملية إن الفرد يتاثز باتجاهات الجماعة التُبي

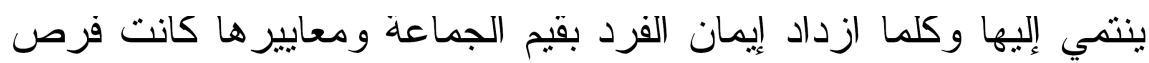

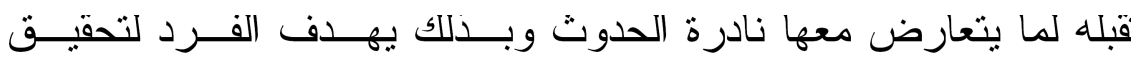

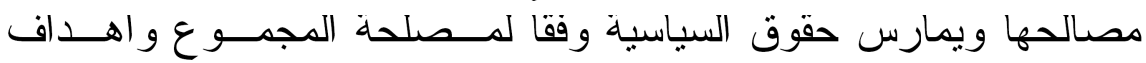


الجماعة، وهذا بطبيعة الحال إلى جانب ممارسته الحقوق السياسية الفردية

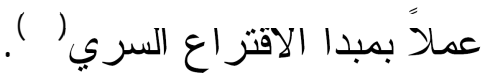

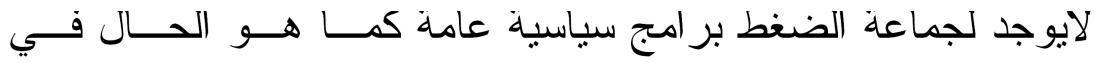

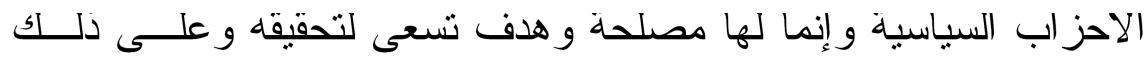

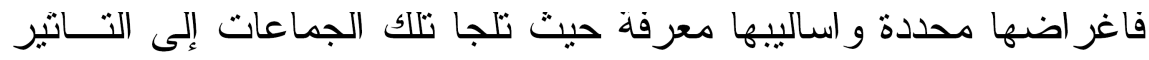

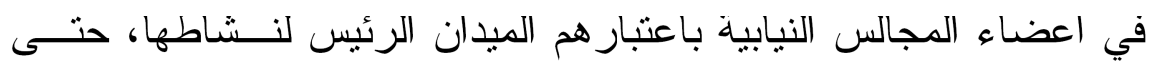

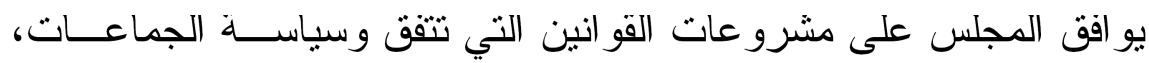
ويرفض مالا بتفق مع هذه السياسية. وتعتمد جماعة الضغط فــي بقائهـيـا

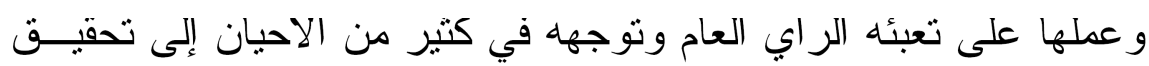

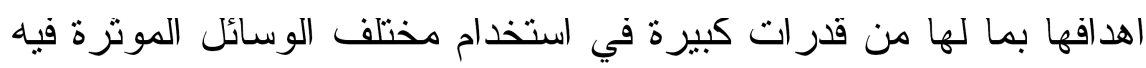

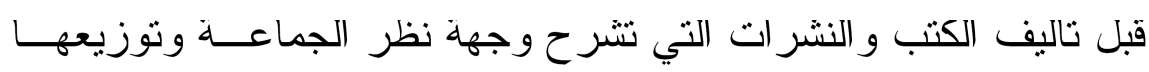

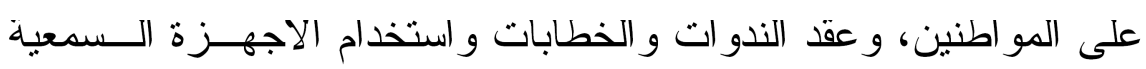

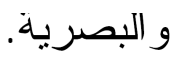

وقد تتفاوت جماعات الضغط بعضها مع بعض لتحقيق اكبر قدر مــن

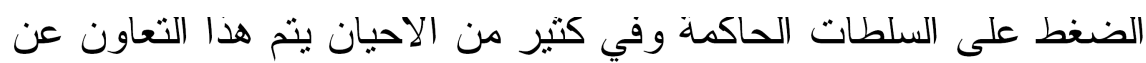

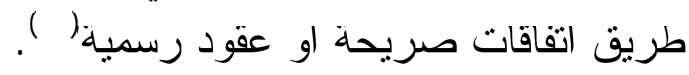

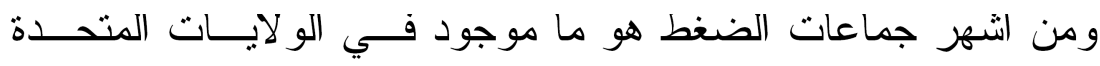

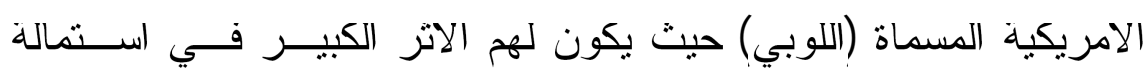

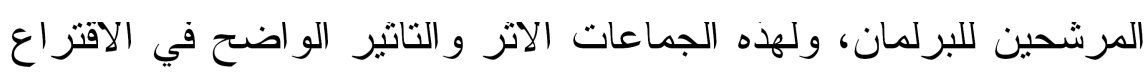

\section{المبحث التالت}

\section{معوهات العمليه الاتتخابيه}

عند در اسة موضوع الديمقر اطية في الدول العربية بجب دائما نــذكر التهر

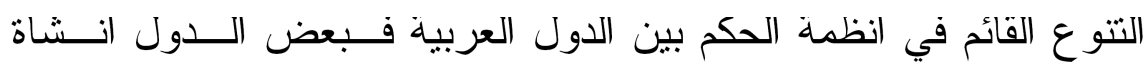




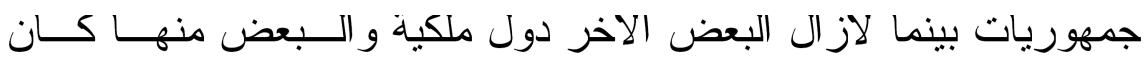
مستعمر أ من قبل الفرنسيين و البعض الاخر استعمره الانكليز و الإيطاليين وفي الوقت الذي يمناز اقتصاد بعض الدول بالقوة تكون هناك دول اخرى الخى اقل قوة اقتصادية لضعف إنتاجها النفطي وقلة تتوع مصادر ها الاقتصادية كل هذا يودي إلى عدم إمكانية توحيد التصور الديمقر اطي تجاه البلـــدان العربية.

فضدا عن ذلك، لا وجود لاتفاق في المنطقة العربية حول كيفية فهــ

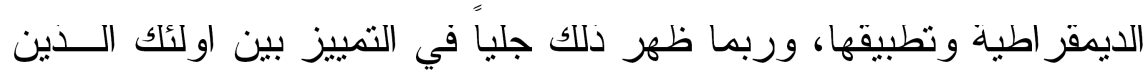

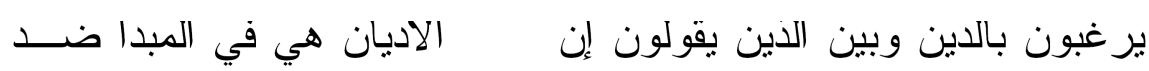
الديمقر اطية. وحتى داخل النظرية السياسية الإسلامية يقــوم التجاهــــان:

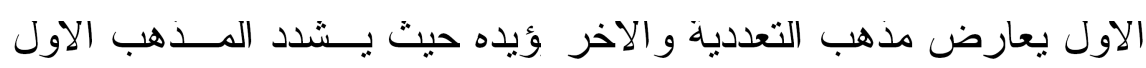

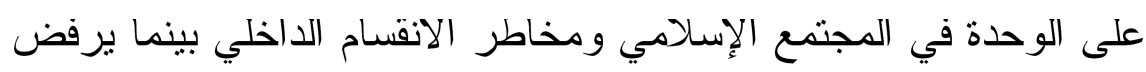
الثاني اي ادعاء انساني اي ادعاءات باحتكار الحقبقة وتدل هذه النظريات الإني

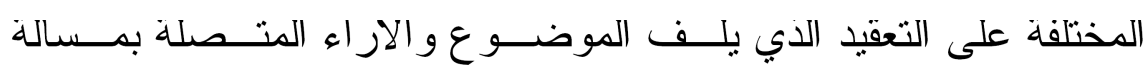
الديمقر اطية في الدول العربية. في هذا المبحث يتناول الباحث معوقات العملية الانتخابية انطلاقا من

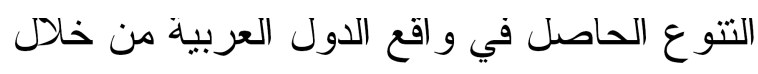
المطلب الاول: الإرث الاستعماري و الثقافة السياسية وهو ينالف من فرعين الفرع الاول: الإرث الاستعماري.

الفرع الثاني: التقافة السياسية.

وفي المطلب التاني: العو امل الاجنماعية و الاقتصادية وطبيعة المجتمــع

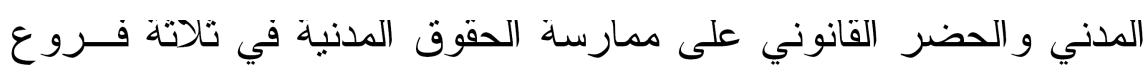

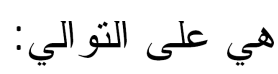
الفرع الاول: العو امل الاجنماعية و الاقتصادية. 
الفرع الثناني: مجتمع مدني ضعيف. الفرع الثالث: الحضر القانوني على ممارسة الحقوق المدنية والاجتماعية.

$$
\text { المطلب الاول }
$$

\section{الإرث الاستعماري و التقاهه السياسيه}

كيف تتكون النقافة السياسية في مجتمع ما وكيف تتنج عنها قيم

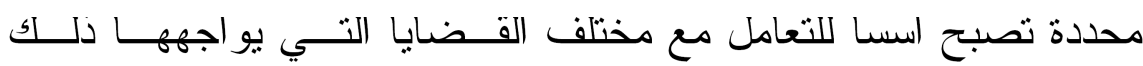

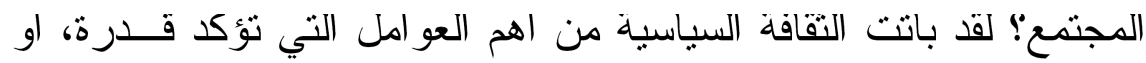

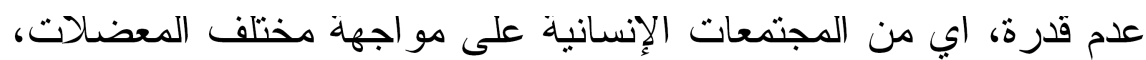

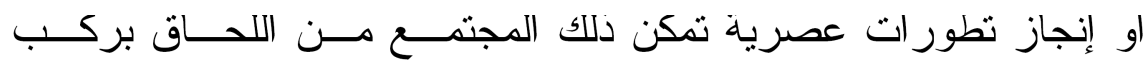

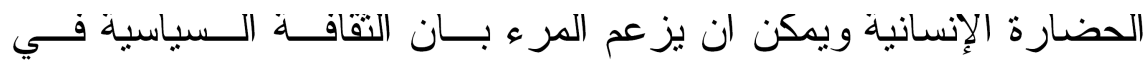

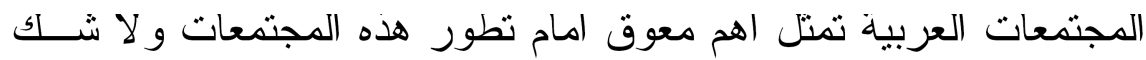

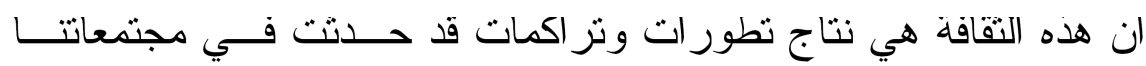

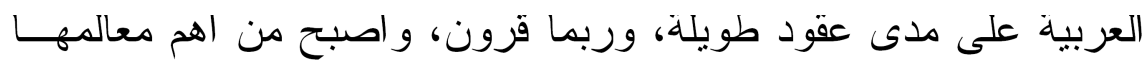

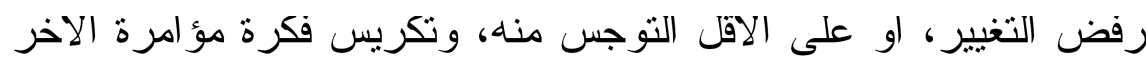

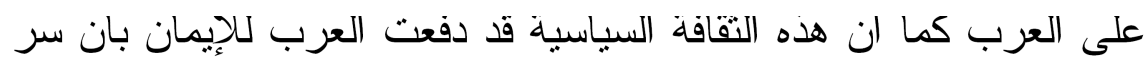

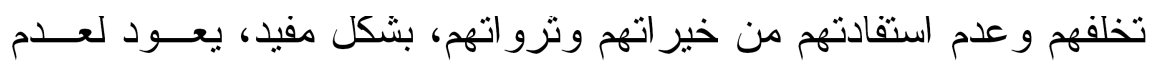

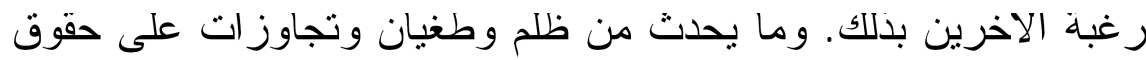

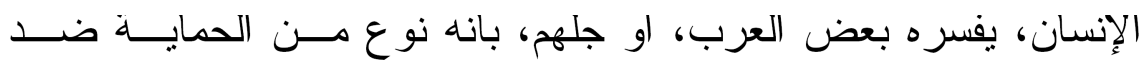

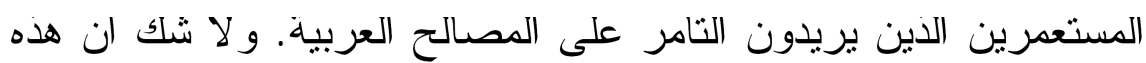

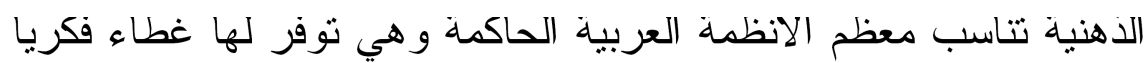

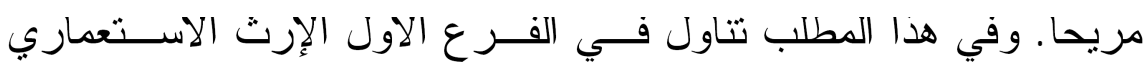
و الفرع الثاني الثقافة السياسية. 


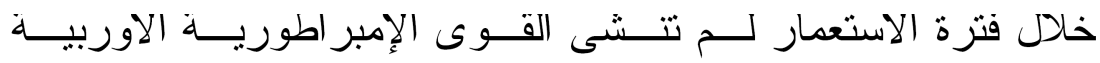

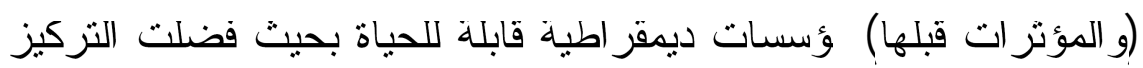

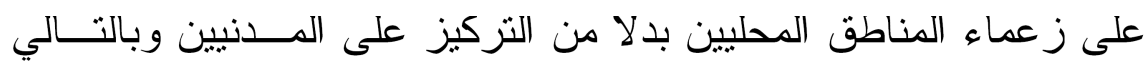

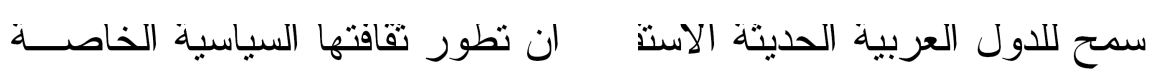

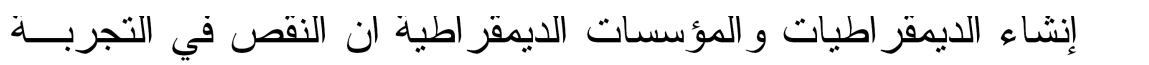

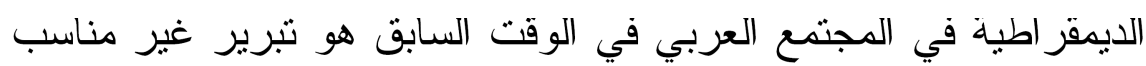

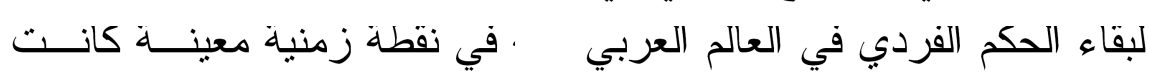

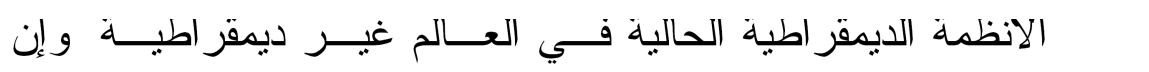

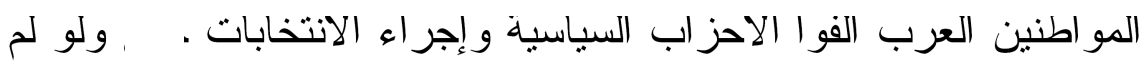

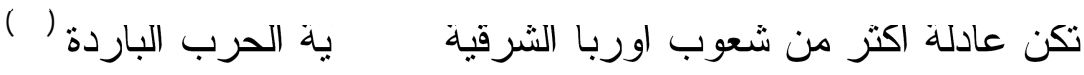

\section{القرع التاني: التقاهه السياسيه} التتقيف السياسي: تقوم الانتخابات الديمقر اطية بدور تنقيفي عام، فهـي

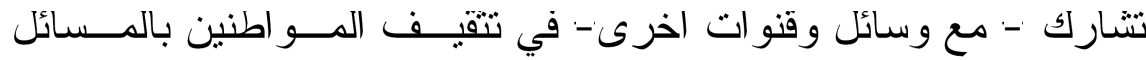
المنصلة بالعمل العام و الثؤون السياسية قبل و اتثناء عمليـــة الانتخابــات،

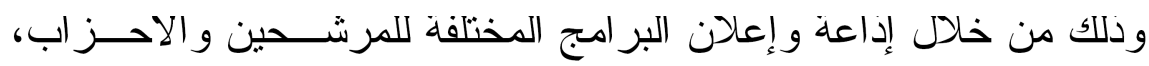
ومواد الدعاية الانتخابية خلال فترة الانتخابات، الامر الذابر الذي ينيح الفرصدة

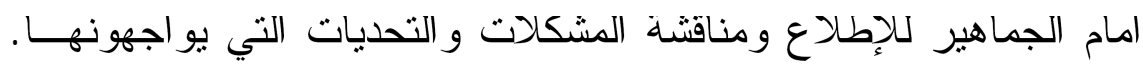

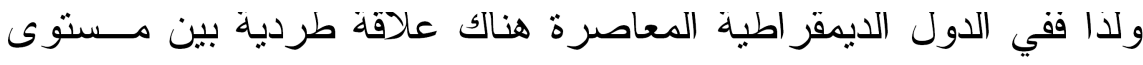
الوعي و الثقافة و التعليم من جهة ومستوى المشاركة في الانتخابات مسنـن جهة اخرى.

و على العكس من ذلك تجد تلك العلاقة سلبية في الكثير من الدول غير

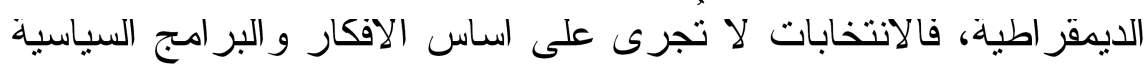


التي تعالج الثـان العام، و إنما على اســـاس الاشـــخاص و اداء الخــدمات

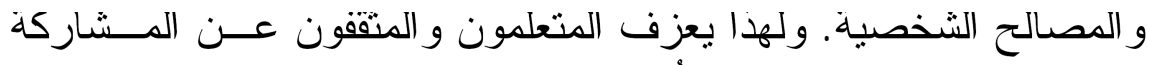

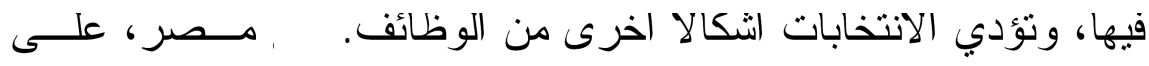

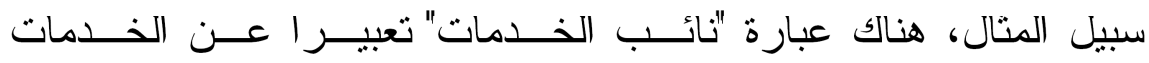

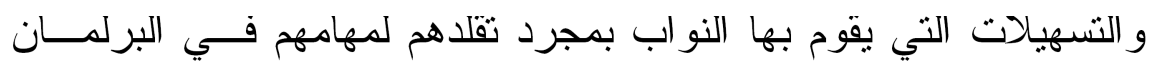
لابناء دائرتهم ومعارفهم (01).

إن التقافة العربية السياسية تتمبز بالبدائية (الو لاءات القومية و العشائرية

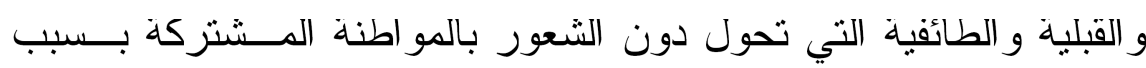
النقص في النسامح التقلبدي الليبر الي للتعددية و الاختلاف وبسبب الذونية بلهية

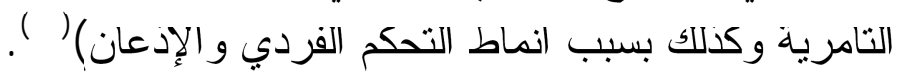

ويرى الباحث ان التقافة السياسية العربية هي ثقافة حديثة النشاة كونها

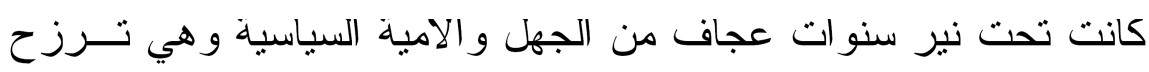
تحت نير الاستبداد العتماني ومن بعد عصر النهضة الاوربية تحت انظمة الأنه الاستعمار الاوربي بمختلف الوانه و اطبافه.

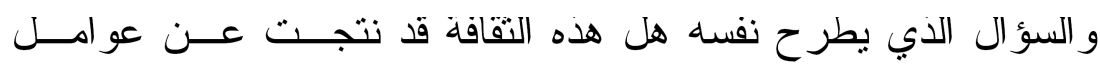

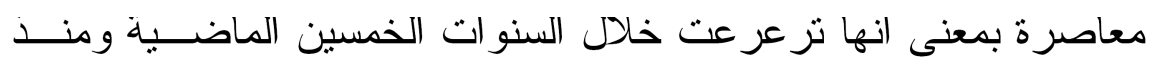

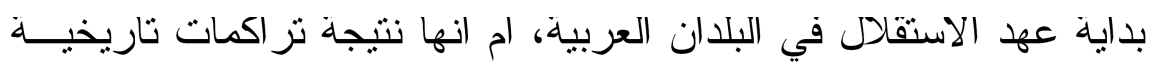
طويلة تقاعلت عناصر ها خلال عهود طويلةّ؛ يمكن القول بان الاحتمالين

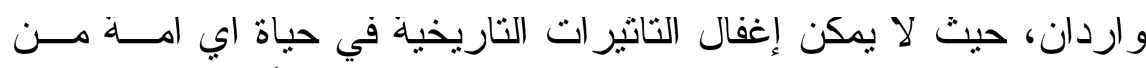

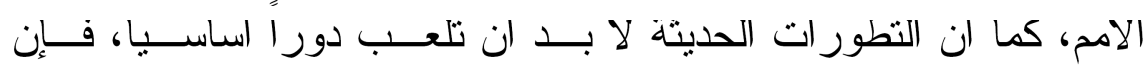

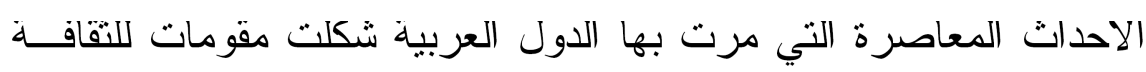

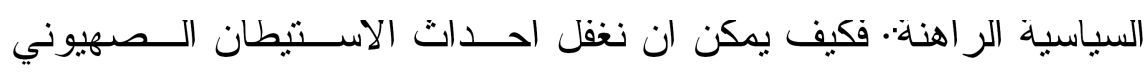

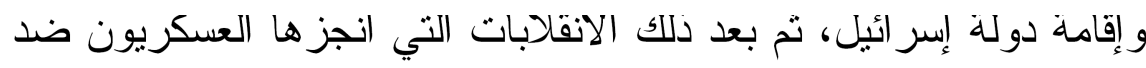

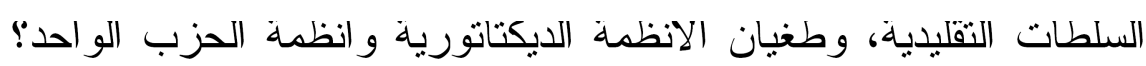

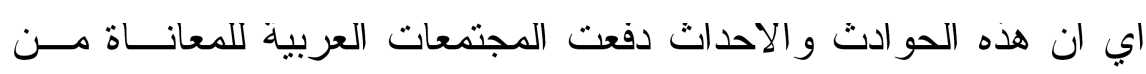


الانظمة الديكتاتورية و استبداد الفكر الثّولي وتسلط فلسفة لا صوت يعلو

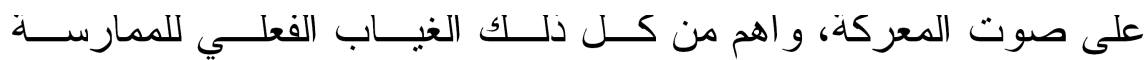

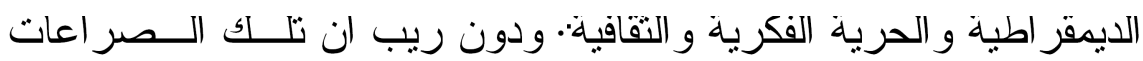

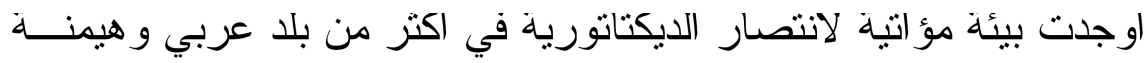

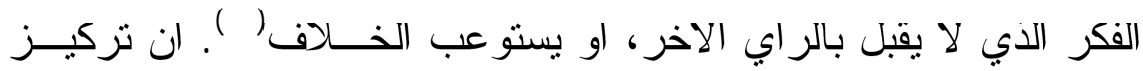

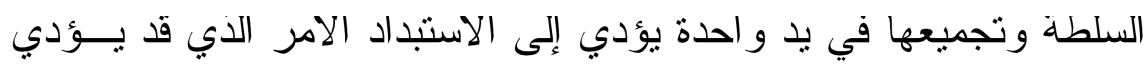

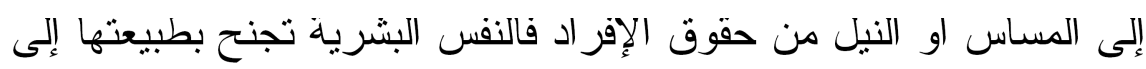

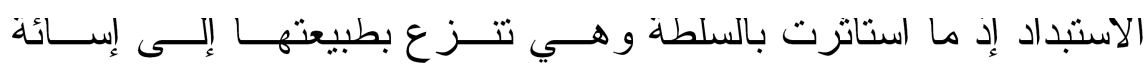

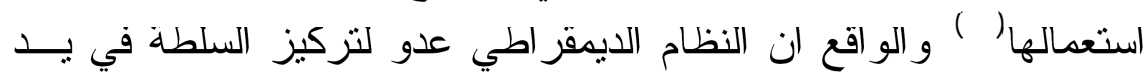

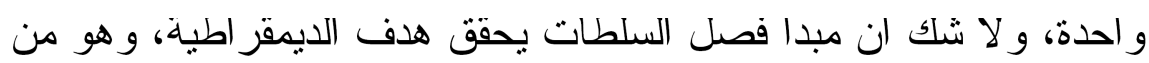
خبر الضمانات لحقوق الافر اد وحرياتهم (00).

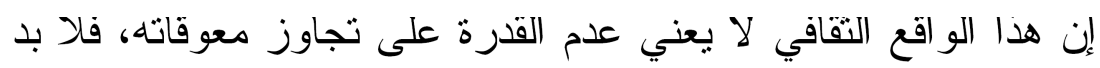

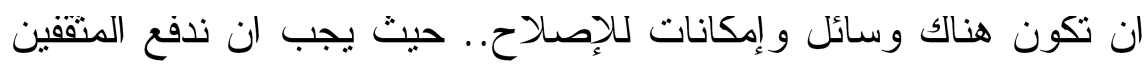

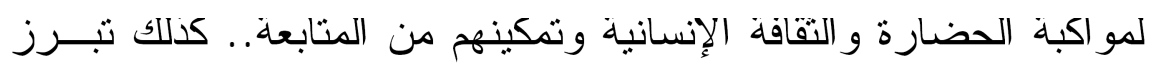

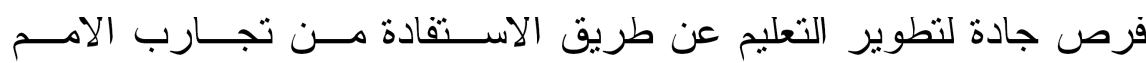

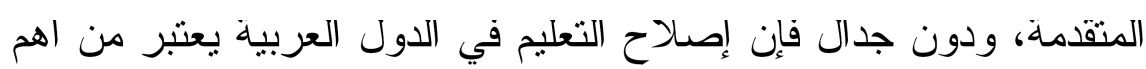
عناصر الإصلاح السياسي وتحديث الثقافة السياسية في اي من المجنمعات

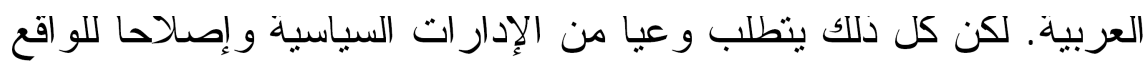

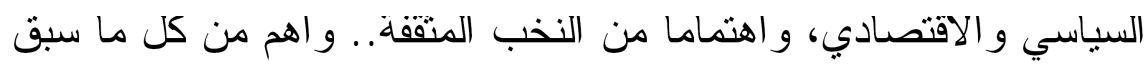

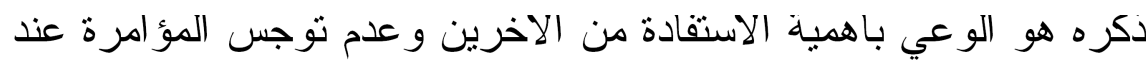

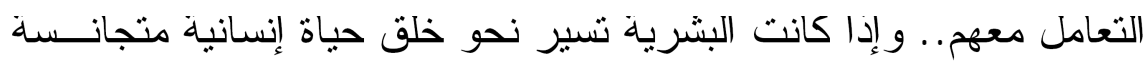

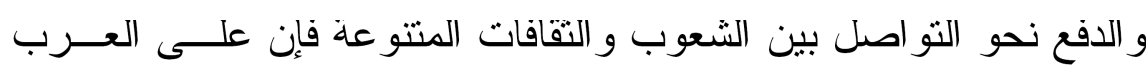
تبني مبدا بالانفتاح ولتو اصل التحرر من الانظمة الشمولية(07). 
العوامل الاجتمـاعيه والاتتصاديه وطبيعه المجتمع المدني

يتتاول في هذا المبحث العو امل الاجتماعبــة و الاقته صـادية وطبيعــة المجتمع المدني و الحضر القانوني على ممارسة الحقوق المدنية في ثناثنة فروع هي على التو الي: التئ الفرع الاول: العو امل الاجتماعية و الاقتصادية. الفرع الثاني: مجتمع مدني ضعيف. الفرع الثالث: الحضر القانوني على ممارسة الحقوق المدنية و الاجتماعية.

القرع الاول: العوامل الاجتماعيه والاقتصاديه: اولا: ان التطور الاقتصادي اتسم بالانتقائية من حيث المشروعات التي تم

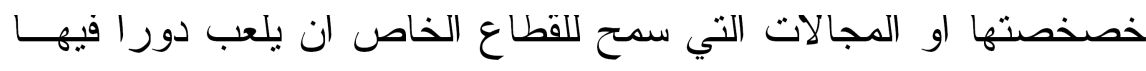

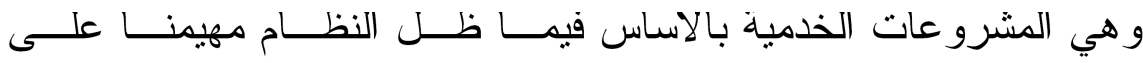
المشرو عات القومبة الكبرى.

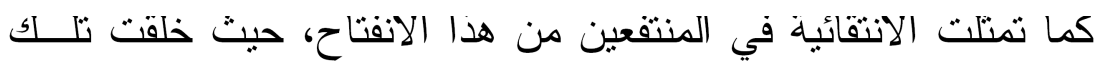

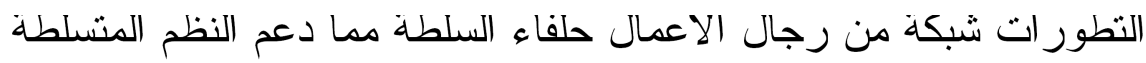

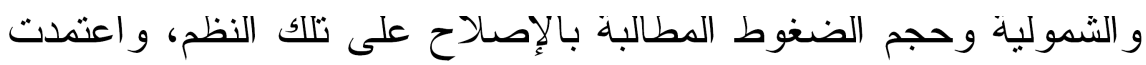
الحكومات في بقائها على شبكة المنتفعين، في حين ان القطاعات العريضة وله

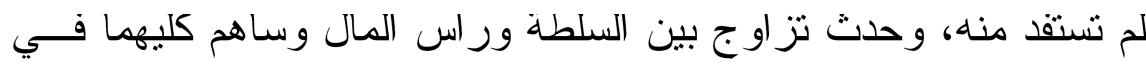

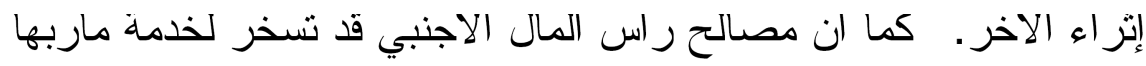
الخاصة انظمة ديمقر اطية المظهر وعلى الاخص البرلمانات التي نسيطر

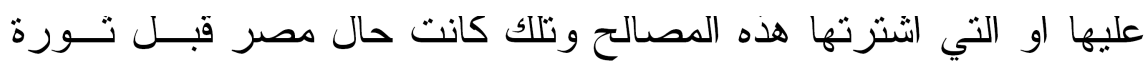
(OV)

ومثلت تلك التطور ات مصدر ا جديدا لتوليــد المــشاكل منتـل غيــاب

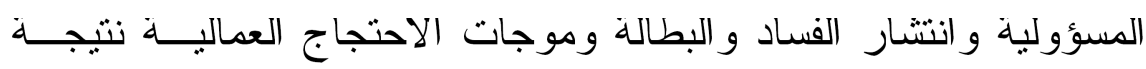


مساوئ الإصـالح الاقتصادي الانتقائي و اتسعت فجــوة الــــخول وعـــدم

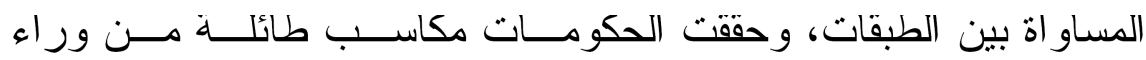
الخصخصة، ونجحت في استغلال عائد تلك السياسات الاقتصادية لإحكام

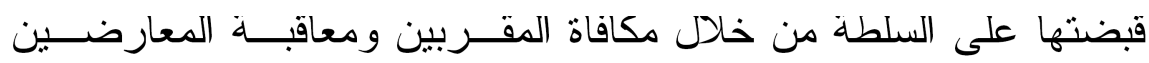

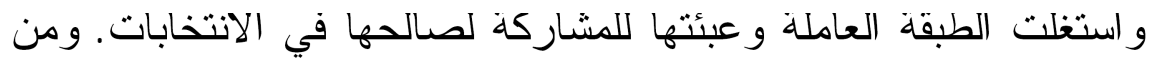

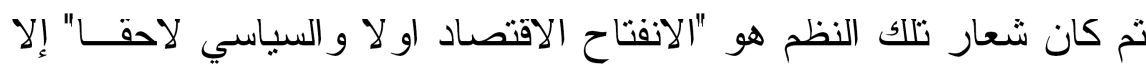
ان ذلك لم يمكنها من استيعاب المد الإسـامي نهاية القرن الماضـــي فــي الإني

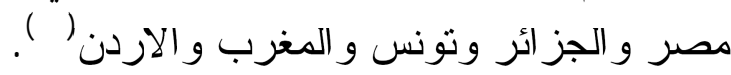

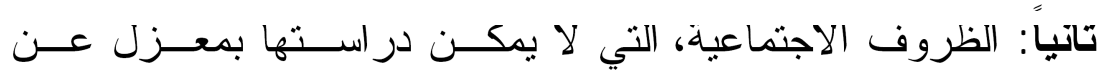

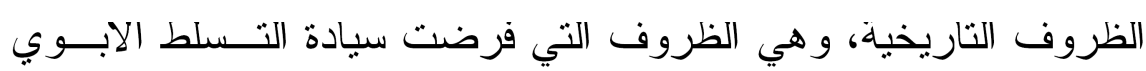

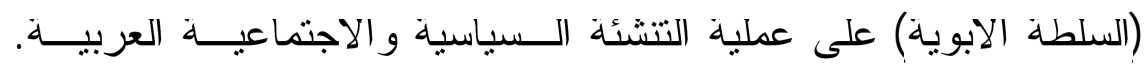

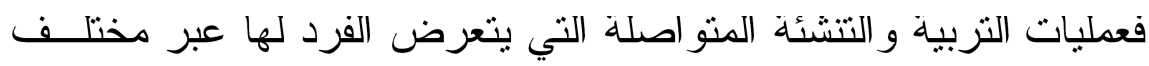
مر احل حياته، و التي يقوم بها العديد من المؤسسات الاجتماعية و السياسية

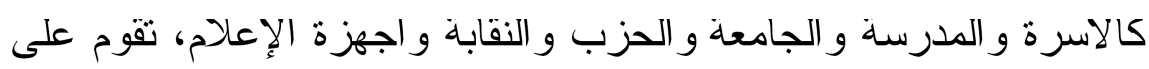

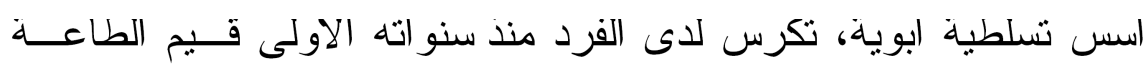

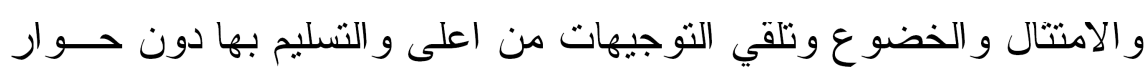
او مناقشة او نقد

يرى الباحث إلى ان العو امل التي سبق ذكرها مجتمعة كان لهــا اتــر

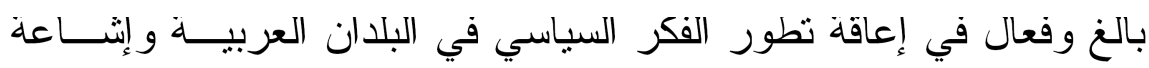

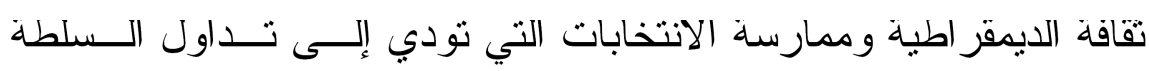
و المشاركة الشعبية في ممارسة الحكم بجميع انو اعه.

\section{القرع التاني: مجتمع مدني ضعيف}

إن منظمات المجتمع المدني القائمة في المنطقة العربية لم تكن قـادرة

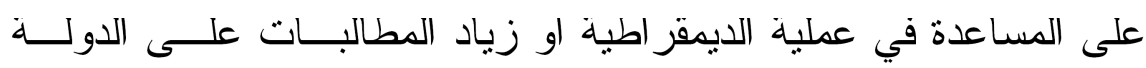


لتصبح اكثر نقبلا ووسيلة من وسائلة لأنها لا تعمل بطريقة ديمقر اطيــة

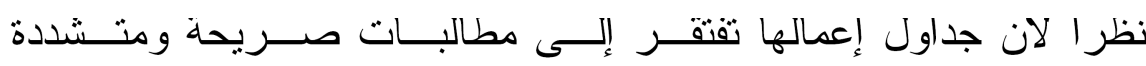
للايمقر اطية السياسية كما انها لم تستجمع القوى الكافية بنفسها او بالتعاون

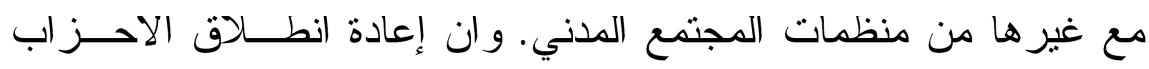
السياسية في الوطن العربي لا يمكن إن بعتبر دليلا على الديمقر اطبة لأنها

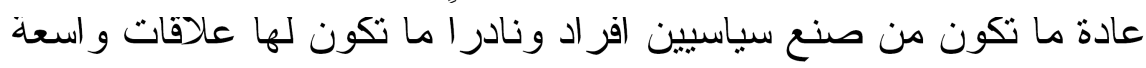

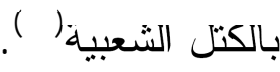

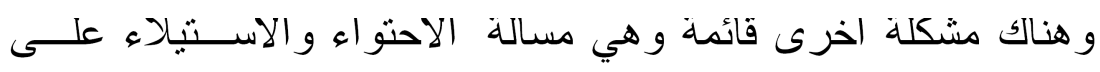

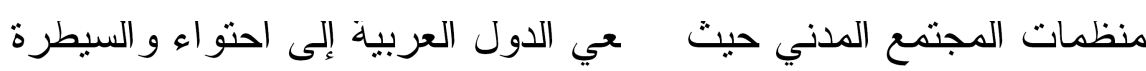

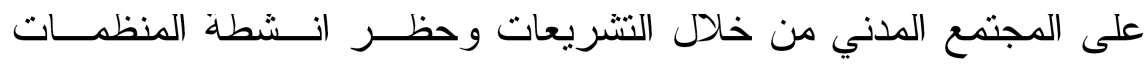
الاهلية. ورغم التوسع في المنظمات غير الحكومية خلال الثمانينات، فإن هذا القطاع لم يتطور بقوة في مصر و الجز ائر و الكويت و المغرب. و علي مدار التسعينات كانت بعض المنظمات غير الحكومية تقوم بدور بدور نشط في الحياة السياسية العربية وعملت على تطوير اجندتها للدفاع عـن فئن

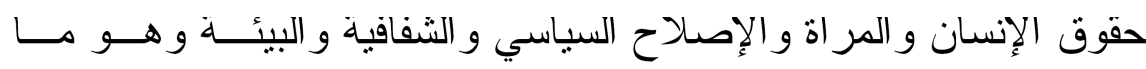

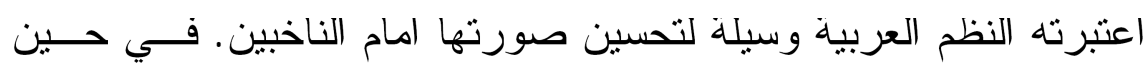

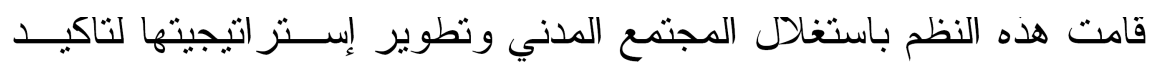

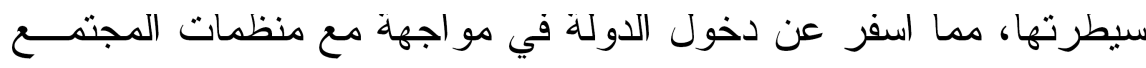
المدني منذ التسعينيات وحتى الان. وقد قامت هذه الانظمة بقمع المنظمات المدافعة عن حقــوق الإنـسـان

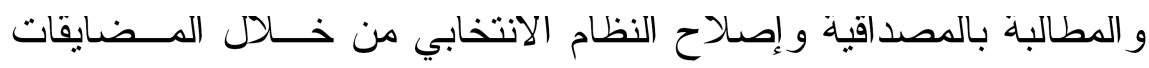

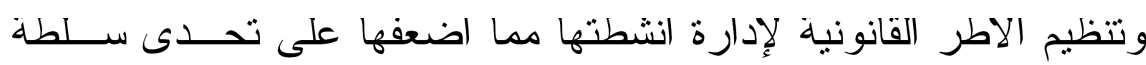
الدولة رغم تعرض تلك الانظمة للانتقادات الحادة ونتويه سمعتها داخليا

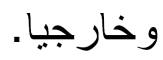


في حين استقادت تلك النظم من بعض المنظمات الاخــرى وبخاصـــة

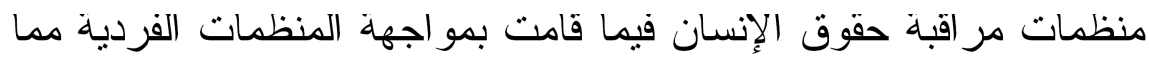
اوجد فر اغا سياسيا و استمرت الانظمة الحاكمة في قمع و الحد من نشاطات

المنظمات الفردية مما ادى إلى ضعف دور وتاثير المجتمع المدني (7اتئ. القرع التالت: الحضر القاتوني على ممارسه الحقوق المدنيه والاجتماعيه للمر اة تعاني المر اة العربية من لجوء الدولة إلي التدابير النشريعية كوســيلة

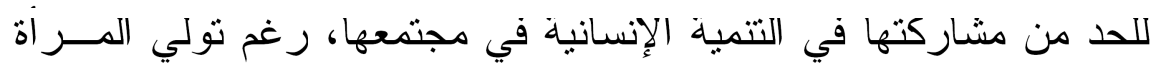

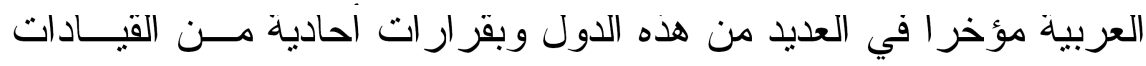

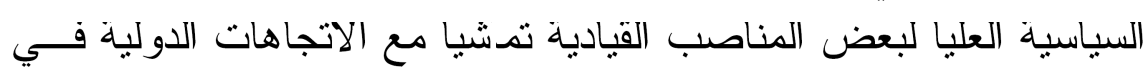

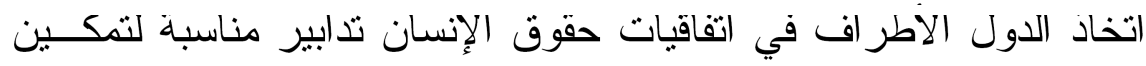

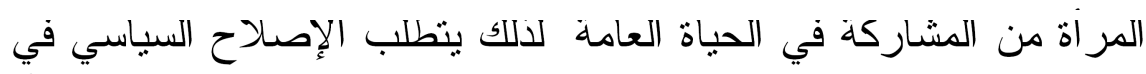

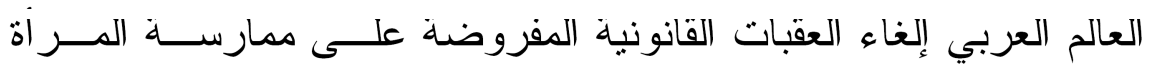

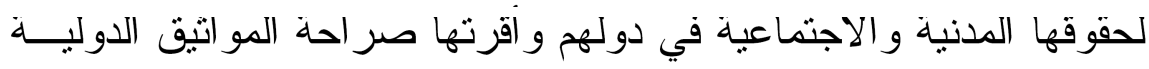

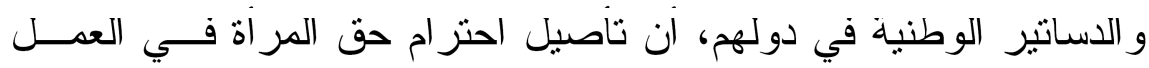

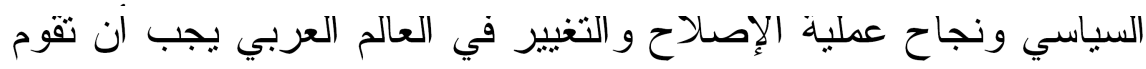

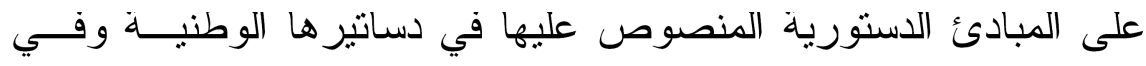

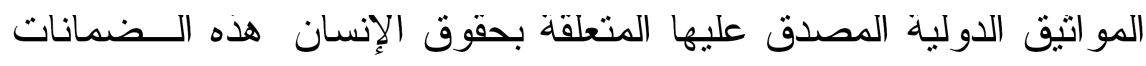

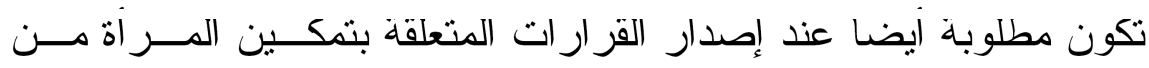

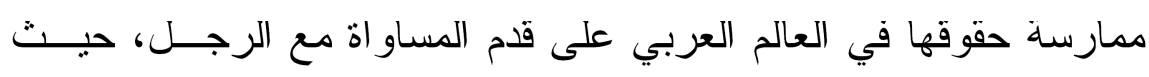

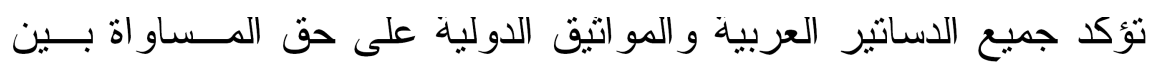

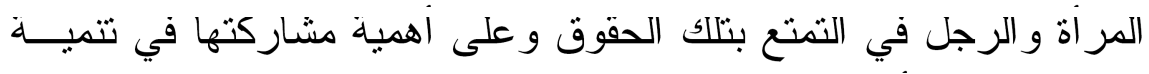
المجتمع، ومن أمتلة تلك الدساتير الدستور العر اقي لعـام

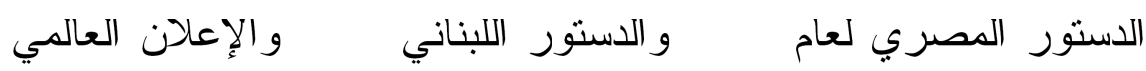
لحقوق الإنسان الصادر عام و العهد الدولي الخاص بالحقوق المدنية 
ومعاهدة إز الـــة

ومعاهدة الحقوق السباسية للنساء

و السياسية

جميع أثكال التمييز ضد المرانه

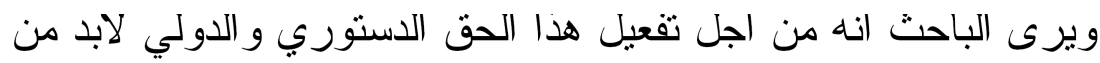

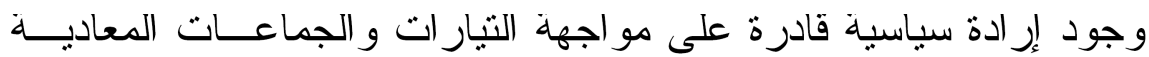

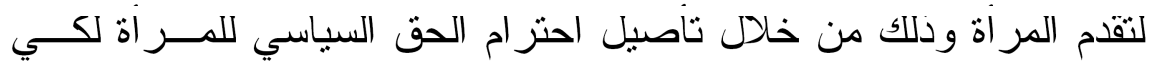
يكون جزء من النسيج التقافي المحلي وهو ليس بالعمل الهين حيث يتطلب

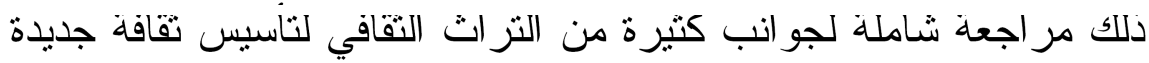

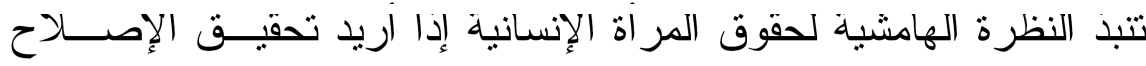
و التغيير الحقيقي في العالم العربي.

أن غياب التخطيط المسبق لتأصيل حقوق المر اة السياسية و الاجتماعيــة

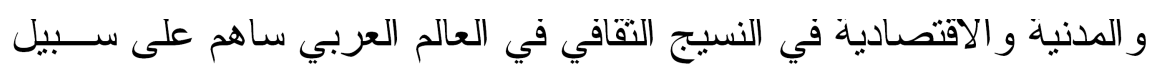

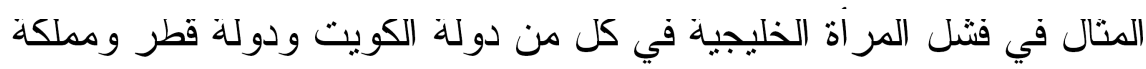

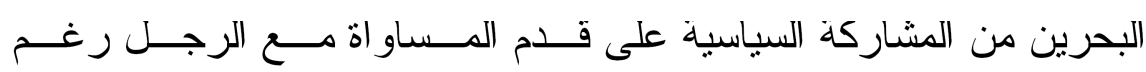

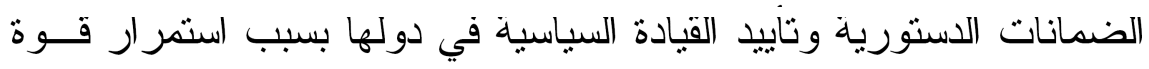

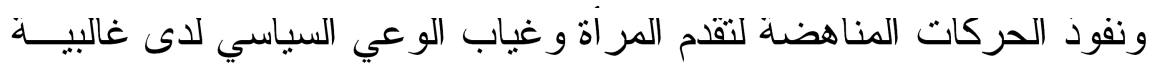

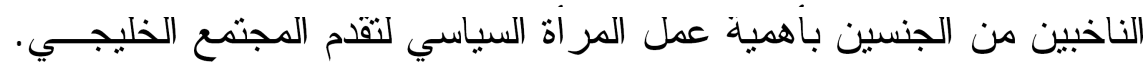
تؤكد دلك تجارب ثلاتة دول من دول مجلس التعاون الخليجي في الفنرة من فن

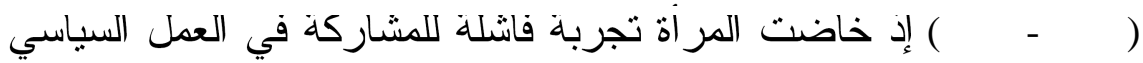

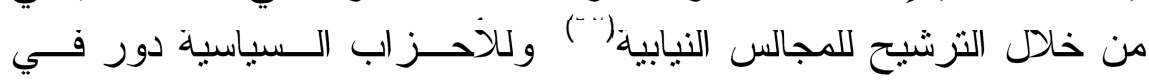

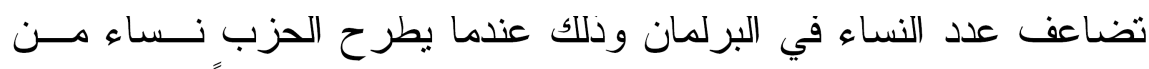

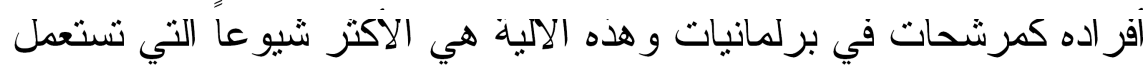
للتزويج لاشتراك النساء في الحياة السياسية وقد استعملت في جنوب الفئ أفريقيا و الارجنتين و الو لايات المتحدة ومن الدول العربية استعملت في العراق في في فئي

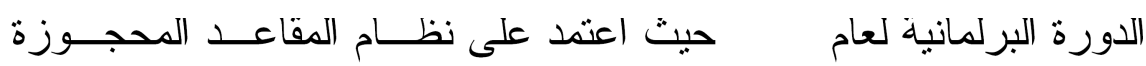

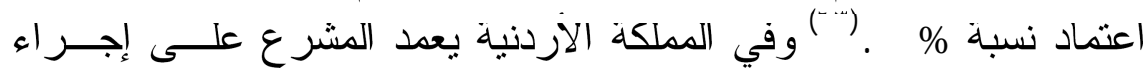
تمييز خاص لصالح المر أة تمنل في حفظ ( ) مقاعد نيابية مخصصة للنساء 


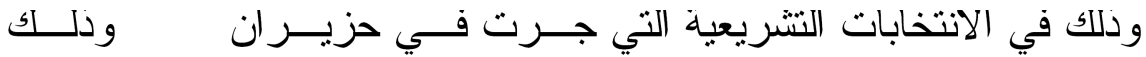

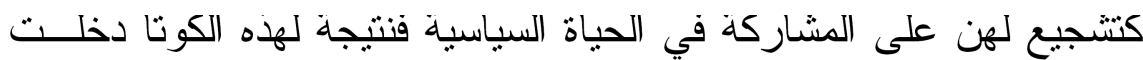

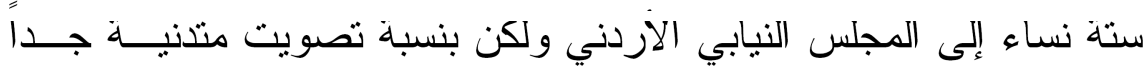

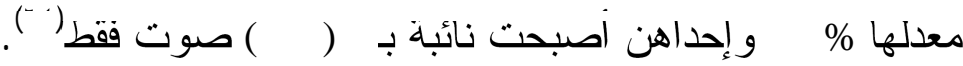

الخاتمه

وفي ختام هذا البحث توصل الباحث إلى عدد من الاستتناجات وهي:

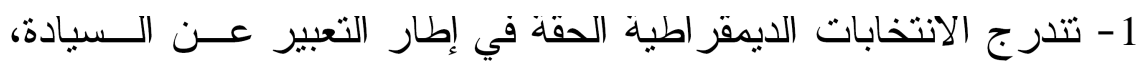
و هو حق مكتسب لشعب اي دولة، كما انها التعبير الحر الذيس الذس ـتبف

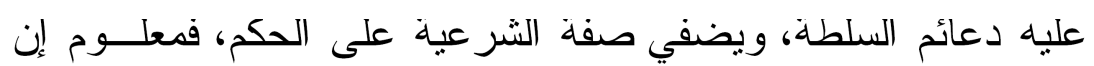
حق المو اطن في ان ينتخب او ينتخب عند إجراء انتخابات ديمقر اطية

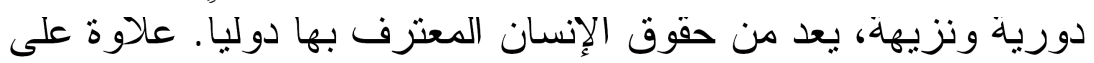

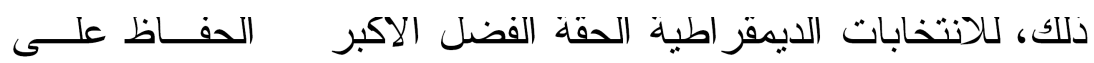
السلم و الاستقر ار ، و هي الني تقوض ممارسة الحكم الديمقر اطي.

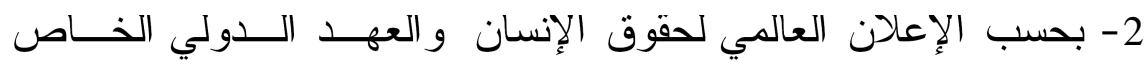

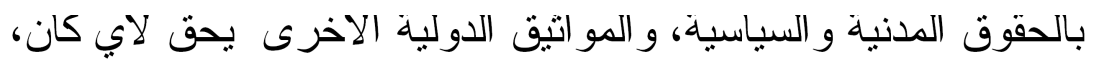

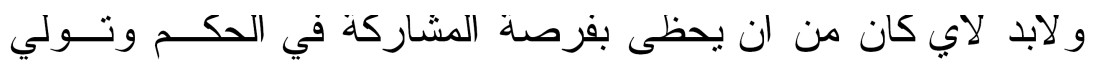

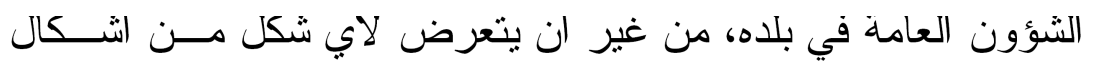

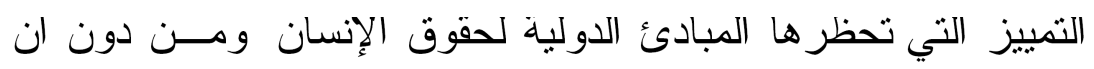
يخضع لقيود مفرطة. يجوز ان بمارس هذا الحق مباشرة، عن طريق الإن ون

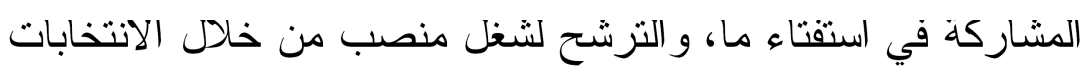
وخلافهما، او يجوز ان يمارسه عبر اختيار ممتليه بحرية.

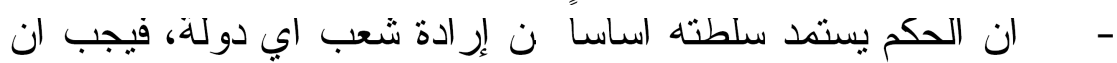

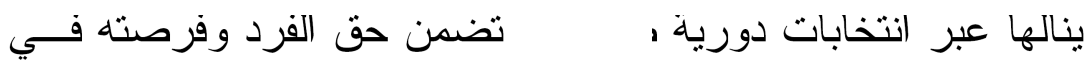

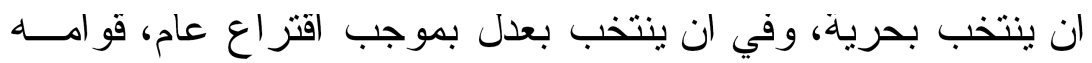

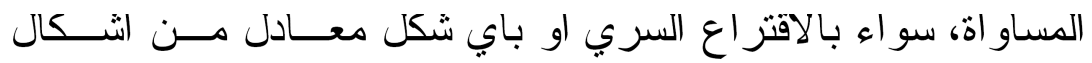


التصويت الحر، الذي يتم فيه فرز النتائج و إعلانها و التقبد بها بمنتهى

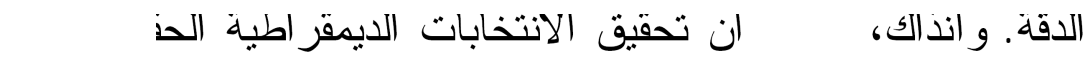
منوطا بعدد هائل من الحقوق، و الحريات، و الإجر اءات، و القـــوانين، و المؤسسات.

4 - تتحم المر اقبة الدولية للانتخابات عن عملية منتظمة، وشلملة، ودقيةــة

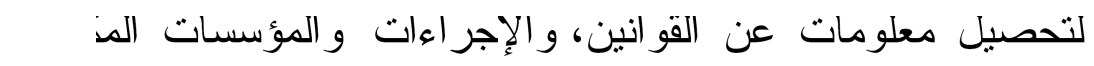

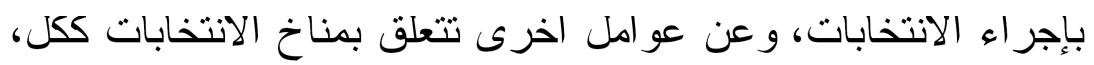
وعن تحليل موضوعي ومحترف لهذه المعلومات؛ و استخلاص العبر

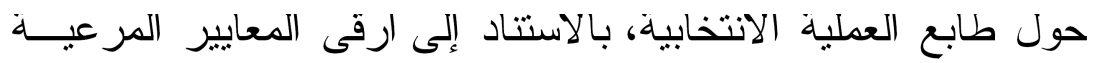

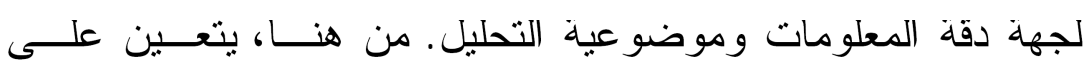
المر اقبة الدولية للانتخابات، حين بيتيسر لها ذلك، ان تصدر توصيات

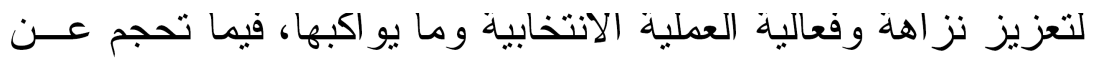

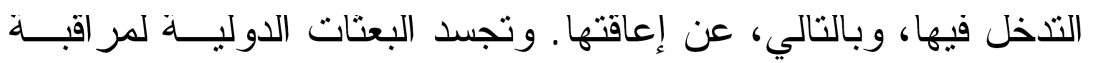

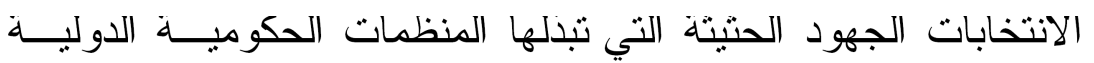
و المنظمات الدولية غير الحكومية وبعض الجمعيات في مجال المر اقبة الدولية للانتخابات.

0 - الانتخابات الديمقر اطية هي انتخابات تتافسية، هذا بعني انه ينبغي ان

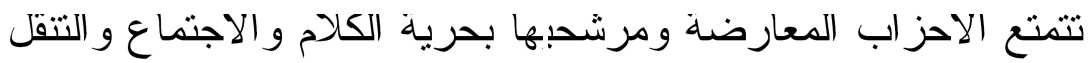

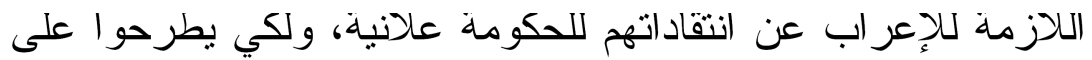

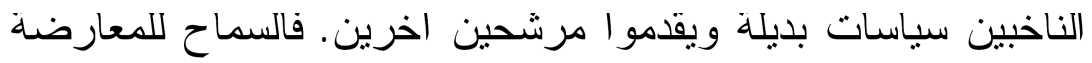

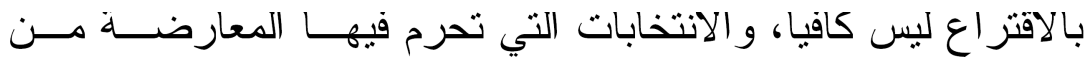

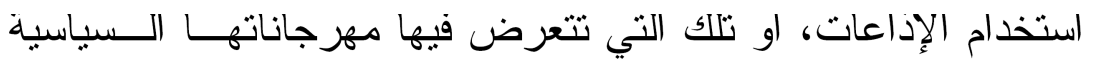

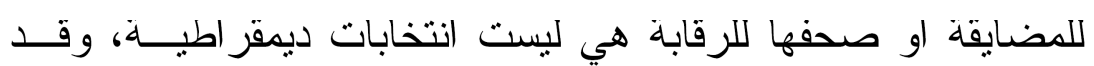
بستقبد الحزب الحاكم في الانتخابات الديمقر اطية من المزابــا التــي 
يوفرها وجوده في السلطة، غير انه ينبغي ان تكون انظمة الانتخابات

$$
\text { وطريقة إجر ائها نفسها نزيهة. }
$$

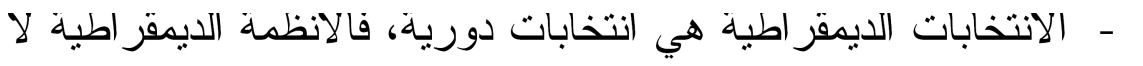

يجري فيها انتخاب دكتاتور او رئيس مدى الحياة. ويكون الرسميون

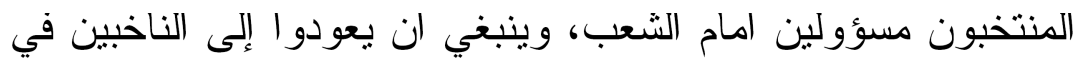
فتر ات محددة سعيا للحصول على تفويض جديد لمو اصــلـة شـــلهم

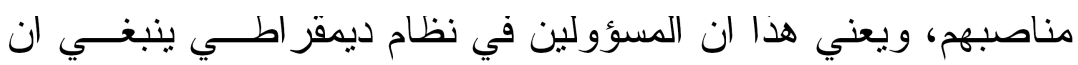

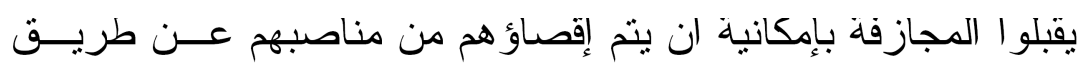

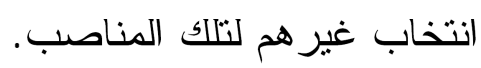
V - الانتخابات الديمقر اطية هي انتخابات شمولية بمعنى ان الاقتر اع يكون

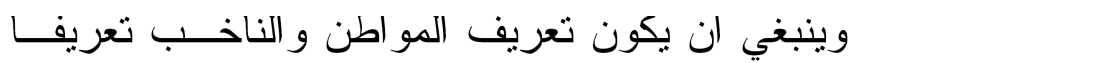

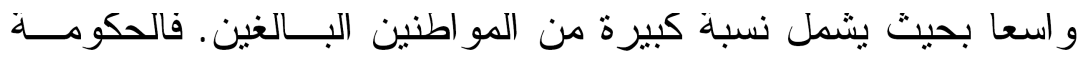

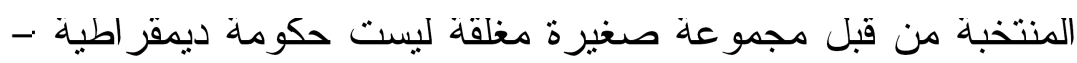
بغض النظر عن المظهر الديمقر اطي لاعمالها الداخلية. ومن الاعمال المؤثرة العظيمة للديمقر اطية عبر التاريخ كفاح المجمو عات المستثناة

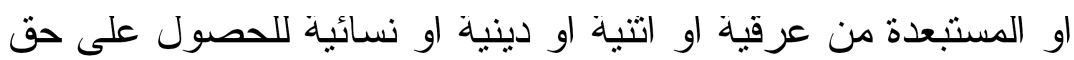
المو اطنة الكاملة ومن ضمنه حق الانتخابات وتولي المناصب العامة. 

العملية الانتخايية في الدول العربية.

\title{
Election in Arab Countries motivation and obstacles
}

\author{
Bassam hayim alshilk \\ A assist lectures/College of political Science/ Univessity of mosul
}

\begin{abstract}
As the electoral processes is essential to build democracy but rather a means or translated and embody the meaning of the participation of the people in power, and its ability to change the acceptable and desired by the legal channels and logic and the correct legal method.

Perhaps that concept is the embodiment of what is happening in most countries of the world, past and present, and here is growing and the means of the contribution of the people in power, deemed the election mechanism the main contribution to the people in politics, defended the electoral process, including that there is the impossibility in the application of direct democracy that the people managing its own political affairs directly without the intervention of a second party has therefore become a semi-direct democracy and representative democracy are applied in the two systems by the ideology of each state and therefore need to be elected by the people of his representative in the exercise of power. The face of the electoral process constraints and obstacles and ballasts fail this process, or empty it of content or limit their effectiveness and the practice of democracy is mounted and a transparent and fair, and limit what can be said that there is the responsibility of rulers to voters who can vote to reject a person or remove him from office, the size of the electorate
\end{abstract}


depends the application of universal suffrage, and notes that the ruling classes have always put the restrictions and obstacles to the many categories of citizens to withhold their vote and thus reduce the size of the electorate to a minimum.

الكهو (مش

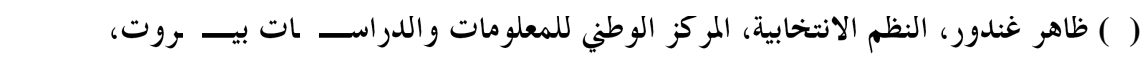

( ) ول ديوارنت، قصة الحضارة، ترجمة جيب محمود واخرون، الدائرة الثقافية في جامعسـة الــدول

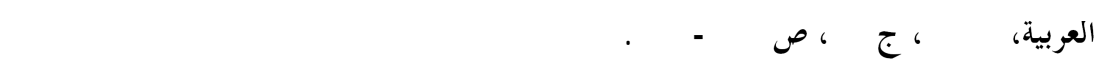

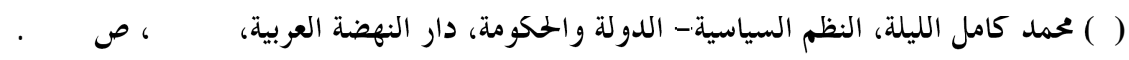

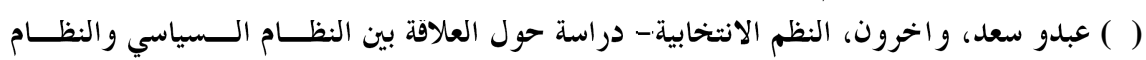

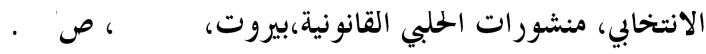

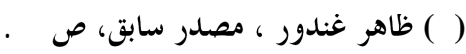

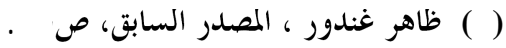

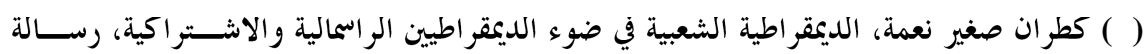

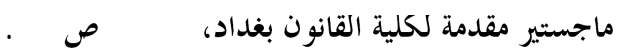

( ) صلاح الدين فوزي، الخيط في النظم السياسية والقانون الدستوري، دار النهضة العربية، القاهرة،

- 1990

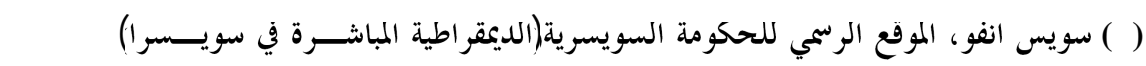

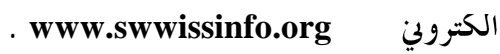

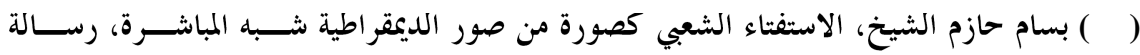

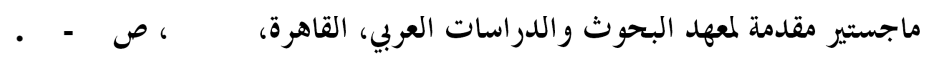

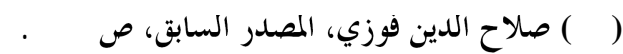

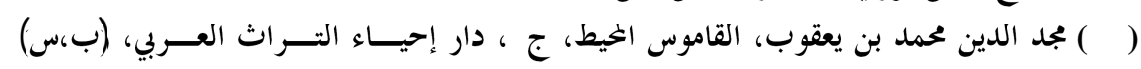

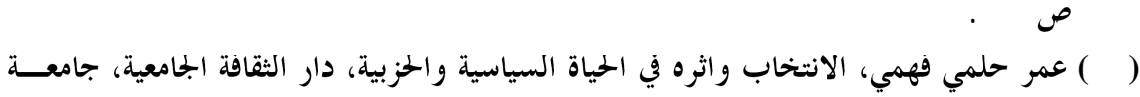

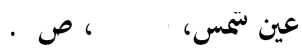

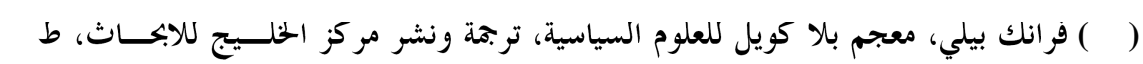

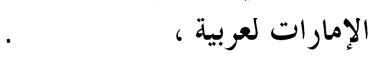




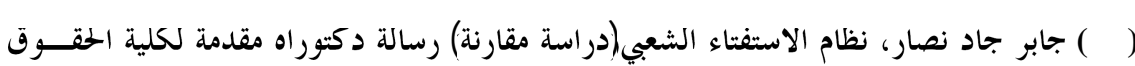

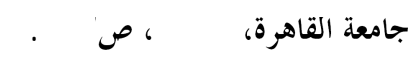

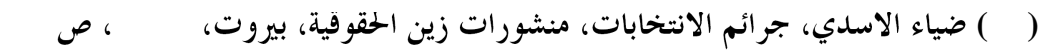

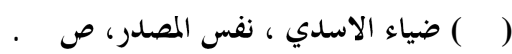

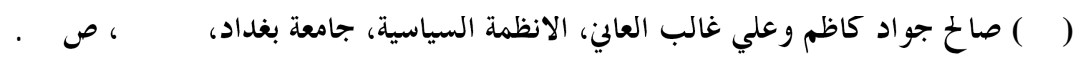

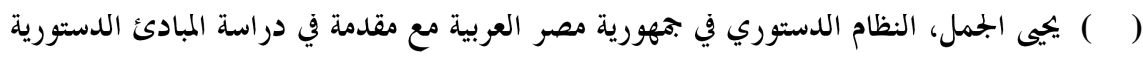

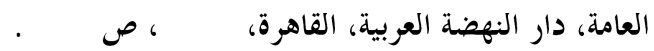

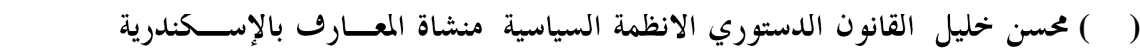
( ) إبر اهيم عبد العزيز شيحا، مبادئ الانظمة السياسيةرالدول،الحكومات)، الدار الجامعية للطباعة

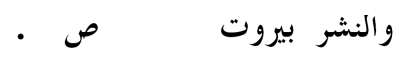

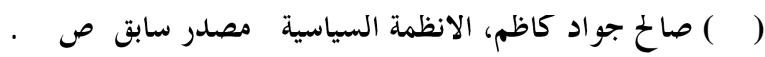

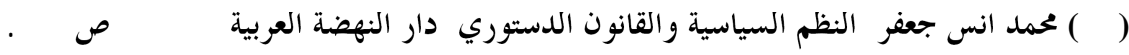

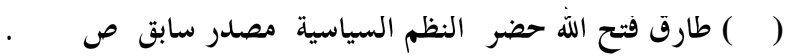

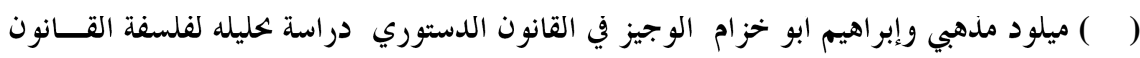

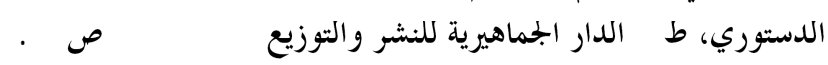

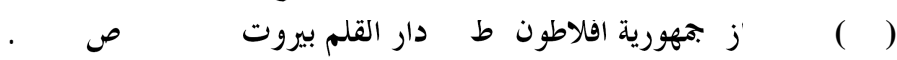

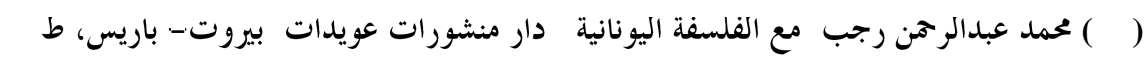

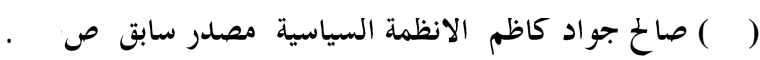

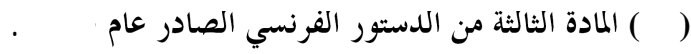

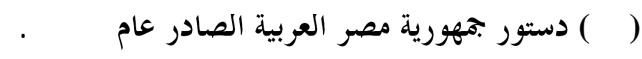

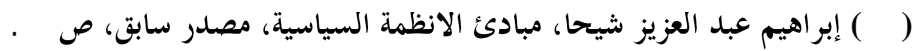

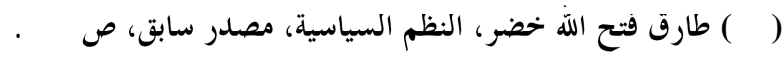

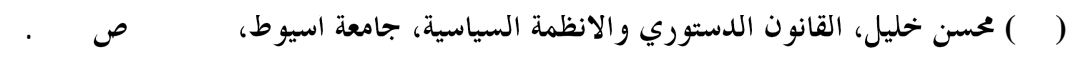

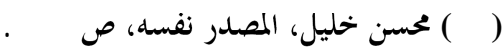

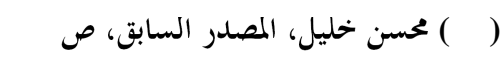

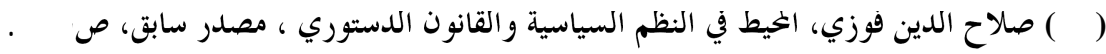

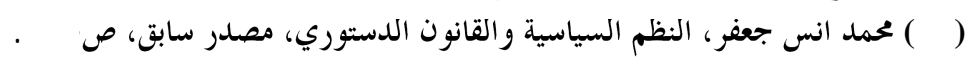

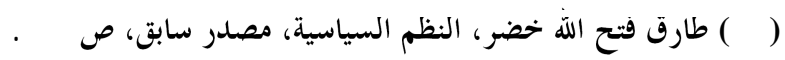




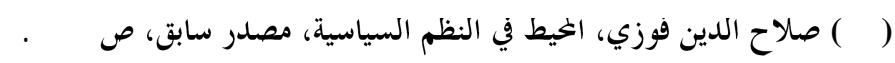

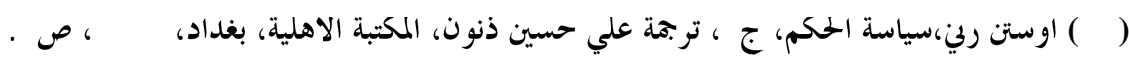

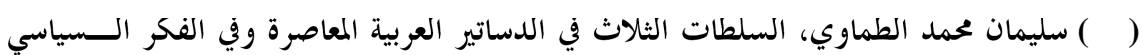

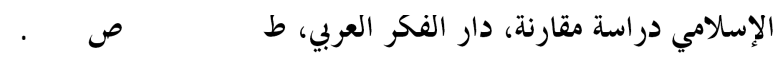

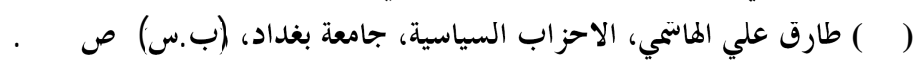

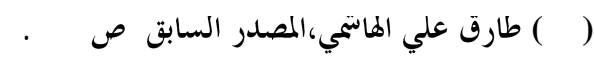

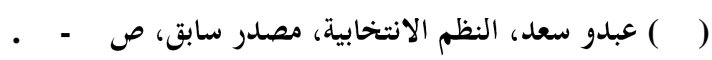

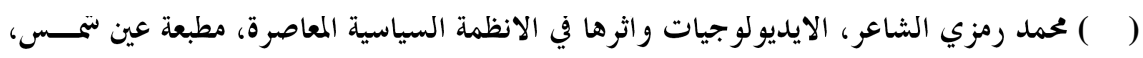

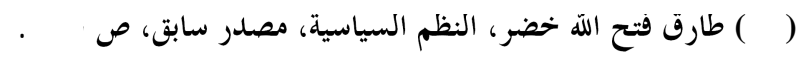

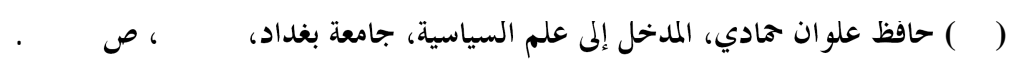

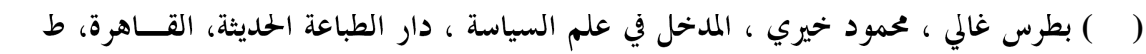

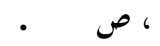

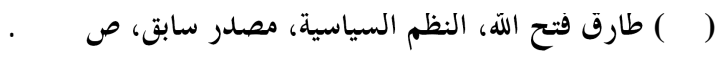

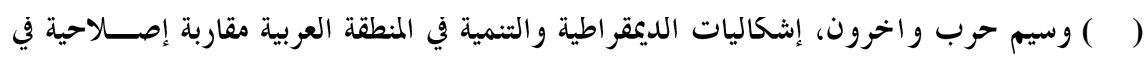

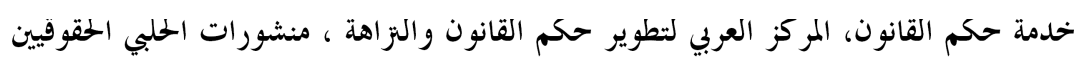

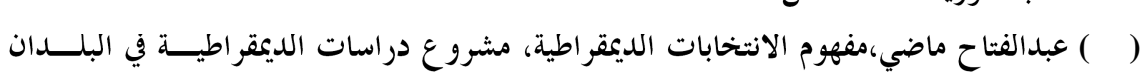

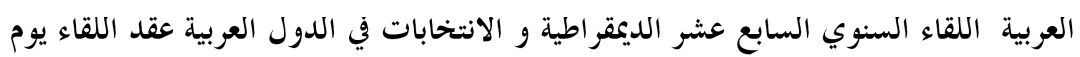

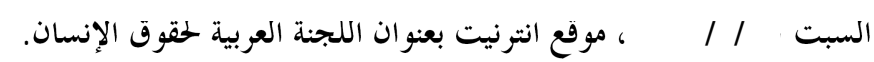

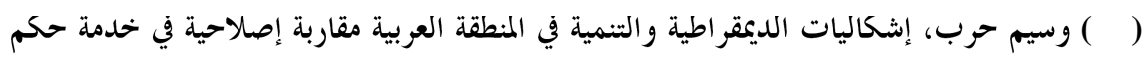

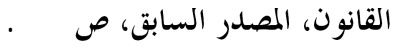

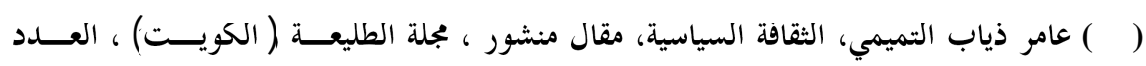

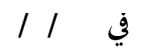

( عبدالغني بسيولي عبد الله، النظم السياسية، اسس الننظيم السياسي، الدار الجامعيــة للطباعـــة

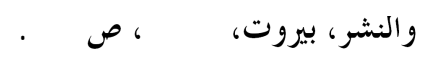

( محمد كامل ليلة، النظم السياسية الدولة والحكومة،دار النهضة العربية للطباعة والنشر، بيروت، 


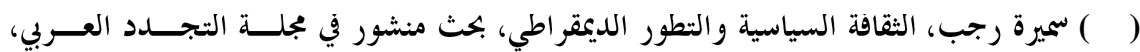

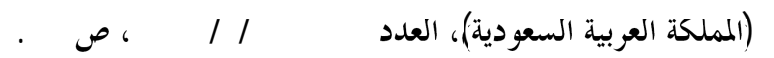

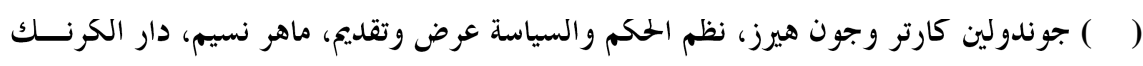

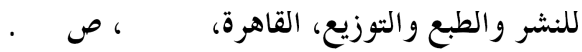

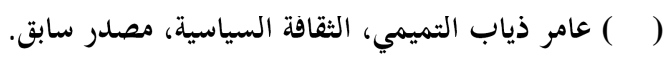

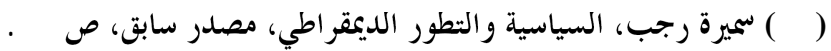

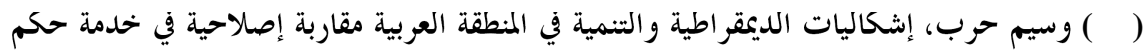

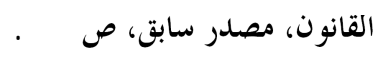

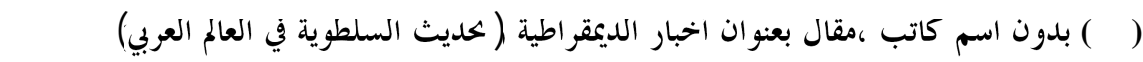

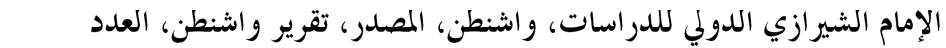

www. Siironline.org

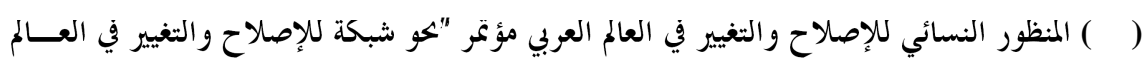

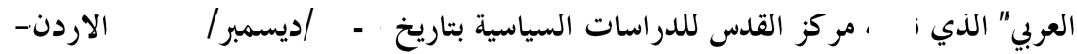

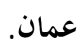

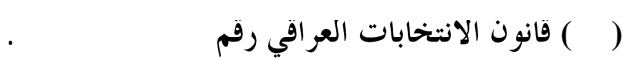

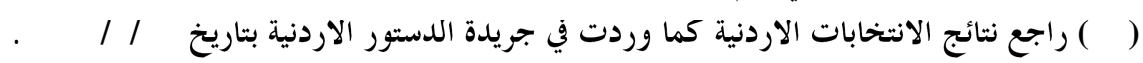

